\title{
Heavy Metals in Wastewater and Sewage Sludge from Selected Municipal Treatment Plants in Eastern Cape Province, South Africa
}

\author{
Mojeed A. Agoro ${ }^{1,2, *(\mathbb{D})}$, Abiodun O. Adeniji ${ }^{1,2, *(\mathbb{D})}$, Martins A. Adefisoye ${ }^{2,3}(\mathbb{D})$ and \\ Omobola O. Okoh 1,2 \\ 1 Department of Chemistry, University of Fort Hare, Private Bag X1314, Alice 5700, South Africa; \\ ookoh@ufh.ac.za \\ 2 SAMRC Microbial Water Quality Monitoring Centre, University of Fort Hare, Private Bag X1314, Alice 5700, \\ South Africa; madefisoye@ufh.ac.za \\ 3 Department of Biochemistry and Microbiology, University of Fort Hare, Alice 5700, South Africa \\ * Correspondence: magoro@ufh.ac.za (M.A.A.); adenijigoke@gmail.com (A.O.A.); \\ Tel.: +27-781-246-437 (M.A.A.); +27-632-152-517 (A.O.A.)
}

Received: 17 August 2020; Accepted: 26 September 2020; Published: 1 October 2020

\begin{abstract}
This study assessed the distribution of five heavy metals ( $\mathrm{Cd}, \mathrm{Pb}, \mathrm{Cu}, \mathrm{Zn}$, and Fe) across the various stages of treatment in three selected sewage treatment facilities and their receiving waterbodies in the Eastern Cape Province, South Africa. Aqueous and solid (sludge) samples were collected monthly from September 2015 to February 2016. Quantitation was achieved by atomic absorption spectrometry after necessary sample preparations. Concentrations of heavy metal cations in the sludge generally varied from $<\mathrm{DL}$ (below detection limit) to $1.17 \mathrm{mg} \mathrm{kg}^{-1},<\mathrm{DL}$ to $0.14 \mathrm{mg}$ $\mathrm{kg}^{-1}, 27.588$ to $69.789 \mathrm{mg} \mathrm{kg}^{-1}$, and <DL to $0.099 \mathrm{mg} \mathrm{kg}^{-1}$ for $\mathrm{Cu}, \mathrm{Cd}$, Fe and Pb; while Zn was below detection all through. Similarly, the levels of $\mathrm{Cu}, \mathrm{Cd}$, and Fe in the influents, effluents, upstream and downstream across the three plants ranged from $<\mathrm{DL}-6.588 \mathrm{mg} \mathrm{L}^{-1},<\mathrm{DL}-0.636 \mathrm{mg}$ $\mathrm{L}^{-1},<\mathrm{DL}-0.878 \mathrm{mg} \mathrm{L}^{-1}$ and $<\mathrm{DL}-0.711 \mathrm{mg} \mathrm{L}^{-1}$, respectively; $\mathrm{Zn}$ and $\mathrm{Pb}$ were less than $\mathrm{DL}$ in all the matrices and study locations. All the contaminants were below hazardous levels in all the sludge and aqueous samples except $\mathrm{Cd}$ which was higher in effluents and surface waters across the board. Wastewater Treatment Plant (WWTP)-A exhibited better removal capacity for Fe (86.6\%), compared to WWTP-B (34.7\%) and WWTP-C (56.9\%). However, the removal of $\mathrm{Cu}$ and $\mathrm{Zn}$ was very poor in all the treatment facilities studied. Carcinogenic and non-carcinogenic risks evaluated were sufficiently low. This suggests that the levels of contamination, even with respect to Cd, was minimal. Nevertheless, efforts should be made to keep the concentrations of these contaminants at levels safe for humans and aquatic organisms. Furthermore, the use of the effluents from these facilities for irrigation should be discouraged to prevent unnecessary build-up of metals in the soil and plants grown with such, as well as subsequent bioaccumulation and biomagnification in the food chain.
\end{abstract}

Keywords: heavy metals; wastewater; sludge; removal efficiency; health risk; surface water

\section{Introduction}

Municipal wastewater is a major source of pollution in aquatic environments [1-5]. The final quality of sewage sludge, which is the main by-product of the wastewater treatment process, largely depends on the chemical composition of the influent wastewater and its treatment processes [6-8]. Various contaminants in the wastewater accumulate in sewage sludge (in the region of 80-90\%), and thus discharge of the sludge into waterbodies would increase organic load tremendously with a corresponding reduction in dissolved oxygen levels and nutrient enrichment $[9,10]$. In most cases, 
processes commonly used in the treatment of wastewater do not guarantee the quantitative removal of many contaminants, and hence could lead to another round of environmental pollution after discharge [2,8]. The contaminants in the discharged wastewater could be biological or chemical in nature.

The most common chemical pollutants in wastewater include heavy metal cations, hydrocarbons, pesticides, nitrogenous compounds, pharmaceutical residues, detergents and phosphorus. Microbiological contamination could be from either animal or human faecal wastes containing different kinds of protozoa, viruses and bacteria, capable of causing diseases in humans [11,12]. Similarly, the treatment of wastewater could be biological or chemical [11]. Biological treatment employs naturally occurring microorganisms to convert the dissolved organic matter in the wastewater into dense biomass, which can be removed from the treated wastewater by sedimentation. The dissolved organic matter serves as food for the microorganisms, and so, the amount of sludge produced is far less environmentally friendly compared to the chemical method; hence, it is more commonly used. However, it is inefficient in the removal of toxic and non-biodegradable compounds. Various technologies used in this process include oxidation ponds, aeration lagoons, anaerobic lagoons, aerobic and anaerobic bioreactors, activated sludge, percolating or trickling filters, biological filters, rotating biological contactors, and biological removal of nutrients [13,14]

The chemical process, on the other hand, seems to be more efficient, although the chemical additives used in most cases are very expensive and quite hazardous to the environment. Besides, a large portion of the pollutants in this category is usually not removed at the end of the process, and the cost of maintenance and regeneration is high. Disposal of the large quantity of sludge generated from this process is another cause for concern. Sludge reuse in agriculture as a soil conditioner is common in many countries because of its high organic matter and nutrient contents [15,16]. However, reports have shown that this exercise often leads inadvertently to the accumulation of pollutants in soils, thus contaminating groundwater by leaching through the soil profile under certain conditions [17,18]. High amounts of certain metallic elements including $\mathrm{Cd}, \mathrm{Ni}$, and $\mathrm{Zn}$ have been found in drainage leachates in New Zealand resulting from soil treatment with sewage sludge [19-21]. Some of the chemical processes frequently used include chemical precipitation, ion exchange, neutralization, adsorption, disinfection (using chlorination/dechlorination, ozone, or ultraviolet radiation) and floatation, among others $[13,14,18,22,23]$.

Heavy metals, i.e., metallic chemical elements with relatively high densities, occur naturally in the environment in varying concentrations. Most heavy metals exhibit toxicity even at lower concentrations [24], and their build-up in body tissues over a period of time could be detrimental to human health [25]. Some of these metals have carcinogenic potential, while others are regarded as mutagens and/or teratogens to humans and animals, subject to dosage and duration of exposure. Heavy metals of primary concern in the environment based on their toxicity include $\mathrm{As}, \mathrm{Cd}, \mathrm{Cr}$, $\mathrm{Cu}, \mathrm{Hg}, \mathrm{Mn}, \mathrm{Ni}, \mathrm{Pb}$, and $\mathrm{Zn}$ [26-28]. Although pollution due to heavy metals is a global concern, levels of contamination vary from place to place. Discharge of industrial, municipal and agricultural wastewaters and sewage into rivers has been identified as a significant route of heavy metals into aquatic resources. They easily adsorb to suspended particles in water, settling down in the riverbed, and are later released into the water column, where they become a potential secondary source of contamination, threatening ecosystems $[25,29,30]$. Other anthropogenic sources of these metallic elements in natural waters include lead in petrol, leaching from the soil by acid rain [31], non-point source run-off, industrial and atmospheric deposition, precipitation, mining and refining operations, landfill, smelting of copper and preparation of nuclear fuels, among others [32-34].

A number of studies in South Africa [35-37] and other regions of the world, including Kenya [38], Iran [39], Tunisia [40], Poland [8], China [41], and the United States [42], among others, have documented heavy metal contaminations in soil and aquatic environments. For instance, Shamuyarira and Gumbo [35] reported the occurrence of high levels of $\mathrm{Cd}, \mathrm{Pb}, \mathrm{Zn}$ and $\mathrm{Cu}$, above the recommended guidelines, in sludge samples collected from five different locations in the Limpopo area of South 
Africa. Similarly high heavy metal concentrations for $\mathrm{Hg}, \mathrm{Ti}, \mathrm{Pb} \mathrm{Cr}, \mathrm{Cd}$ and $\mathrm{Ni}$ were recorded in soil and some wastewater samples by Kinuthia et al., while investigating the levels of heavy metals in wastewater and soil from open drainage channels in Nairobi, Kenya [38]. Many of these studies highlighted the human and environmental health hazard posed by the accumulation of these metals.

The three wastewater treatment plants selected in this study were chosen because of their pollution history, demonstrating a number of organic pollutants, and their influence on the receiving waterbodies. Prior studies in the plants include the determination of the physicochemical properties of the wastewater effluents [43,44], phenolic compounds in effluents and receiving waterbodies [45], phthalate esters in influents, effluents, and sludge samples [46] and organochlorine pesticides in their sewage sludge [47]. From the physiochemical quality parameters reported by Agoro et al. [37], deterioration in the surface water quality was evident, especially with respect to the values of TDS, Temp, pH, DO, nitrate, nitrite, phosphate, faecal coliform, chloride, BOD, sulphate, ammonium ion, COD and alkalinity. There was no stability in the reduction/removal efficiency estimated in some plants; besides, electrical conductivity and turbidity fell out of limits in the three treatment facilities. No study has thus far investigated the levels of heavy metals in these sewage treatment facilities and their possible health risks to humans. Besides, as far as we know, no previous study exists on their capacities for the removal of hazardous metals. Hence, this study aimed at evaluating the levels of five metallic elements $(\mathrm{Cd}, \mathrm{Cu}, \mathrm{Pb}, \mathrm{Zn}$, and $\mathrm{Fe})$ in the influents, effluents, and sludge from the three domestic sewage treatment facilities in Eastern Cape Province of South Africa, as well as in their receiving watersheds. Removal efficiencies of these plants and possible health risks of the metals to the ecosystem were equally estimated.

\section{Materials and Methods}

\subsection{Study Area Description}

The three municipal wastewater treatment plants investigated in this study are located in the Eastern Cape Province of South Africa. The plants are located in Alice (WWTP-A), Bedford (WWTP-B) and Berlin (WWTP-C), with geographical coordinates $32^{\circ} 47^{\prime} 55^{\prime \prime} \mathrm{S}, 26^{\circ} 50^{\prime} 95^{\prime \prime} \mathrm{E} ; 32^{\circ} 41^{\prime} 15^{\prime \prime} \mathrm{S}, 26^{\circ} 06^{\prime} 29^{\prime \prime}$ $\mathrm{E}$; and $32^{\circ} 50^{\prime} 70^{\prime \prime} \mathrm{S}, 27^{\circ} 37^{\prime} 04^{\prime \prime} \mathrm{E}$, respectively (Figure 1). WWTP-A uses activated sludge technology, while WWTP-B and WWTP-C use oxidation pond and biofilter technologies, respectively. The WWTP-A, WWTP-B and WWTP-C belong to Raymond Mhlaba, Nxuba, and Buffalo City Municipalities of the Province, respectively [44,45]. WWTP-A has a capacity of $2 \mathrm{~mL} / \mathrm{d}$ for 80,000 people who engage mostly in farming. WWTP-B has a working capacity of $0.5 \mathrm{ML} / \mathrm{d}$ for urban and farming activities, serving almost 30,000 residents. Berlin WWTP-C has a capacity of $1 \mathrm{ML} / \mathrm{d}$ and it serves approximately 68,000 residents, including those involved in farming and industrial $(\sim 40 \%)$ activities.

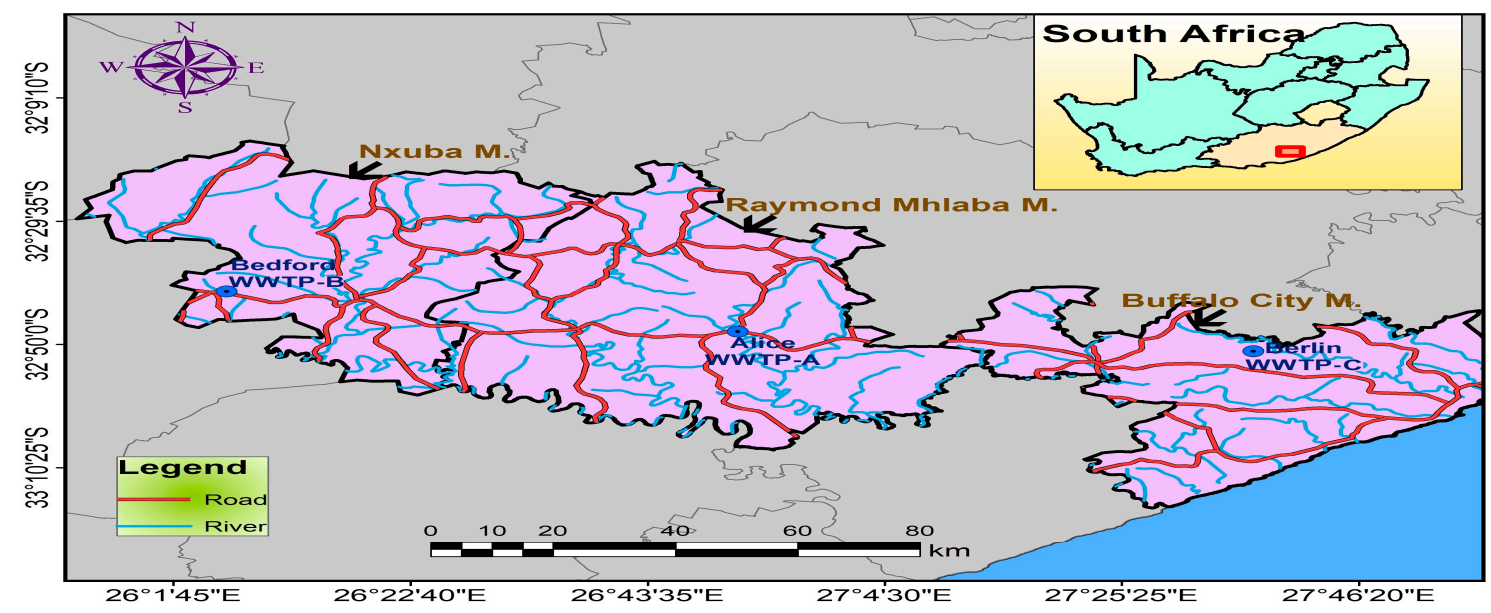

Figure 1. Location of the investigated area. 


\subsection{Preparation of Samples}

Samples were taken once every month between September 2015 and February 2016, spanning two seasons: spring (September to November) and summer (December to February). Samples taken were usually of suburban and agricultural origins. Composite samples of influent, effluent and river water were collected into $2 \mathrm{~L}$ polyethene bottles previously washed with nitric acid and well rinsed with distilled water. The samples were collected in a continuous sweeping motion extending the mouth of the bottle to the run-off discharge and were preserved with a few drops of concentrated $\mathrm{HNO}_{3}$ (adjusted to $\sim \mathrm{pH} 2.0)[44,46,48]$.

Surface water samples were obtained from $500 \mathrm{~m}$ upper stream and $500 \mathrm{~m}$ downstream of the receiving watershed in WWTP-A. This was, however, not possible in WWTP-B where the final effluent was being collected for irrigation of a golf course adjacent to the treatment plant and for construction work in the neighbourhood. At WWTP-C, the final effluent is a branch of the Nahoon River that flows for a long distance. Hence, the river upstream was inaccessible, but the downstream sample was collected about $600 \mathrm{~m}$ away from the point of discharge. Grab samples of sludge $(n=3)$ were taken from each of the facilities into $2 \mathrm{~L}$ broad-mouth bottles from dehydrated activated sludge cake, being the final residue of the sewage treatment processes. Sludge samples from each sampling location were mixed as a composite in a stainless-steel bucket $[45,47]$.

All the samples were immediately taken from the points of collection to the laboratory for analysis in a cooler box containing ice. They were kept refrigerated at $4{ }^{\circ} \mathrm{C}$ for a period of $24 \mathrm{~h}$ after collection, after which they were processed for analysis. The sludge samples were air-dried at room temperature for about $96 \mathrm{~h}$, ground for homogeneity, sieved through a mesh of $1.7 \mathrm{~mm}$ pore size and stored at $-4{ }^{\circ} \mathrm{C}$ before extraction [47]. All solutions in this study were prepared with double-distilled water, and all chemicals used were of analar grade bought from Merck Chemicals (Germany).

\subsection{Sample Preparation}

Ten millilitres $(10 \mathrm{~mL})$ of concentrated $\mathrm{HNO}_{3}$ were added to a $100 \mathrm{~mL}$ portion of each water sample in a $125 \mathrm{~mL}$ conical flask, and the mixture was slowly boiled on a hotplate until the volume reduced to about $20 \mathrm{~mL}$. This was cooled to room temperature, after which another $5 \mathrm{~mL}$ concentrated $\mathrm{HNO}_{3}$ was added. The heating continued with successive addition of $5 \mathrm{~mL}$ portions of concentrated $\mathrm{HNO}_{3}$ at interval as necessary until digestion was completed. The remaining aqueous mixture was evaporated to dryness, cooled and reconstituted in $5 \mathrm{~mL}$ of $\mathrm{HCl}$ solution $(1: 1 \mathrm{v} / \mathrm{v})$. The solution was then warmed before the next addition of $5 \mathrm{~mL} \mathrm{NaOH}(5 \mathrm{M})$, and subsequent filtration through a Whatmann No. 1 filter paper. The filtrate was finally transferred to a $100 \mathrm{~mL}$ volumetric flask and made up to the mark with double distilled water as described by [49-51]. Double-distilled water was treated in the same way as the sample and was used as a reagent blank in the study [25,52].

Similarly, sludge samples were digested with nitric acid in accordance with Environmental Protection Agency (EPA) guidelines. A measure of $2 \mathrm{~g}$ of already ground sewage sludge sample was placed in a conical flask containing $20 \mathrm{~mL}$ of $\mathrm{HNO}_{3}(55 \%)$ and heated at $90{ }^{\circ} \mathrm{C}$ for $45 \mathrm{~min}$. The temperature was later increased to $150{ }^{\circ} \mathrm{C}$ and held for $10 \mathrm{~min}$. Periodic addition of $10 \mathrm{~mL}$ of $\mathrm{HNO}_{3}(55 \%)$ was made thrice while heating of the sample mixture continued to prevent dryness. The mixture was then allowed to cool to room temperature, followed by filtration through Whatmann Number 1 filter paper. Then the sample digest was transferred into a $100 \mathrm{~mL}$ standard flask and made up to the mark with double distilled water as required [53].

\subsection{Instrumental Analysis}

Flame atomic absorption spectrophotometer (Thermo Fisher Scientific, Johannesburg, Gauteng, South Africa) Model Ice 3500 with Shimadzu, Wizard software was used in determining the amounts of the four selected heavy metals $(\mathrm{Cu}, \mathrm{Zn}, \mathrm{Fe}$, and $\mathrm{Pb})$ with a suitable lamp for each at wavelengths, $\lambda_{\max }(\mathrm{nm})$ of 324.8, 213.9, 248.3, and 283.3 in that order. Furthermore, the air/acetylene flame used was 
set at flow rates (L/min) of 1.1, 1.2, 0.9 and 1.2, respectively, for the analyses [54,55]. A graphite furnace system connected with the AAS (Atomic Absorption Spectrophotometer) was employed in the analysis of cadmium (Cd) with a hollow cathode lamp at a wavelength of $228.80 \mathrm{~nm}$. Triplicate measurements were taken for each metallic element, and the results were reported as mean concentrations with standard deviations $[52,56]$. Signal to noise ratio in this study was determined as the ratio of the mean value to the standard deviation of eight replicate analyses of the least level of calibration standard for each metal, and the result was above 5 as required. The instrument detection limit (IDL) was thereafter calculated as the product of three multiples of standard deviation (38) and student $t$ value of the replicate determinations at a $99 \%$ confidence level $[57,58]$. The IDLs for $\mathrm{Cd}, \mathrm{Cu}, \mathrm{Pb}, \mathrm{Fe}$ and $\mathrm{Zn}$ were $0.03,0.02,0.03,0.03$, and $0.04 \mathrm{mg} \cdot \mathrm{L}^{-1}$, respectively. Heavy metals' concentrations in the blanks and samples were determined by way of extrapolation on the prepared calibration curves. Blank results were deducted from those of the samples to eliminate errors attributable to impurities in the reagents used for the experiments [25,52]. The removal efficiency of each wastewater treatment facility, which implies the percentage ratio of the concentration of selected regulated contaminants removed during the treatment process to the total amount present in the influent water before the treatment, was estimated using Equation (1) below [59].

\subsection{Removal Efficiency of Wastewater Treatment Facilities}

$$
\text { Removal efficiency }(\%)=\frac{C_{i}-C_{e}}{C_{i}} \times 100
$$

where:

$C_{i}=$ mean concentration of heavy metal in influent

$C_{e}=$ mean concentration of heavy metal in effluent

\subsection{Health Risk Assessment}

Possible health risks to humans after exposure to certain chemicals in the environment is assessed by way of three different steps, which include identification of hazard, exposure assessment and risk assessment [60,61]. Exposure could be by ingestion/oral intake, dermal contact or inhalation. A number of heavy metals are identified as being toxic with adverse health effects on humans. These include specifically, arsenic, cadmium, chromium, copper, lead, mercury, molybdenum, nickel, selenium, and zinc, as stated in the United States Environmental Protection Agency (USEPA) Part 503 rule [62]. In this study, impacts on human health of five of these metals (iron, copper, cadmium, lead and zinc) detected in the sewage sludge samples were assessed using their average daily doses, ADD (mg kg-1 day $^{-1}$ ) by ingestion and dermal contact as stated in Equations (2) and (3) below [63,64].

$$
\begin{gathered}
\mathrm{ADD}_{\text {ingest }}=\frac{\mathrm{C}_{\mathrm{s}} \times \mathrm{IR}_{\text {ingest }} \times \mathrm{EF} \times \mathrm{ED} \times \mathrm{CF}}{\mathrm{BW} \times \mathrm{AT}} \\
\mathrm{ADD}_{\text {dermal }}=\frac{\mathrm{C}_{\mathrm{s}} \times \mathrm{SA} \times \mathrm{AF} \times \mathrm{ABS} \times \mathrm{EF} \times \mathrm{ED} \times \mathrm{CF}}{\mathrm{BW} \times \mathrm{AT}}
\end{gathered}
$$

where $\mathrm{ADD}_{\text {ingest }}$ is the average daily dose for ingestion $\left(\mathrm{mg} \mathrm{kg}^{-1}\right.$ day $\left.^{-1}\right)$; $\mathrm{ADD}_{\text {dermal }}$ is the average daily dose for dermal contact ( $\mathrm{mg} \mathrm{kg}^{-1}$ day $\left.^{-1}\right) ; \mathrm{C}_{\mathrm{s}}$ is the mean concentration of heavy metals in the sewage sludge sample $\left(\mathrm{mg} \mathrm{kg}^{-1}\right)$; $\mathrm{IR}_{\text {ingest }}$ is the ingestion rate of heavy metals $\left(100 \mathrm{mg} \mathrm{day}^{-1}\right.$ for adults and $200 \mathrm{mg} \mathrm{day}^{-1}$ for children); $\mathrm{EF}$ is the exposure frequency (350 days year ${ }^{-1}$ ); ED is the exposure duration (30 years for adults and 6 years for children); BW is the average body weight (70 kg for adults and $16 \mathrm{~kg}$ for children); AT is the averaging time (for non-carcinogens, $\mathrm{ED} \times 365$ days, and for carcinogens, 70 years (lifetime) $\times 365$ days); $\mathrm{CF}$ is a unity conversion factor $\left(1 \times 10^{-6} \mathrm{~kg} \mathrm{mg}^{-1}\right)$; SA is the exposed skin area $\left(5700 \mathrm{~cm}^{2}\right)$; AF is the adherence factor $\left(0.07 \mathrm{mg} \cdot \mathrm{cm}^{-2}\right)$ : and ABS is the dermal absorption fraction (0.001 for each metal) [25,65-68]. 


\subsubsection{Non-Carcinogenic Risk Assessment}

Hazard quotient, HQ depicts the tendency of any non-carcinogenic risk or chronic toxicity that may arise after a long-time exposure of humans to a non-carcinogenic heavy metal and it is unitless. It is estimated from either of the ADDs already defined in Equations (2) and (3) above and the respective reference dose (RfD) for individual metallic element as shown in Equation (4). It is regarded as the highest value below which no adverse health effect befalls the exposed person $[63,68]$.

$$
\begin{aligned}
& \mathrm{HQ}=\frac{\mathrm{ADD}}{\mathrm{RfD}} \\
& \mathrm{HI}=\Sigma \mathrm{HQs}
\end{aligned}
$$

$\mathrm{RfD}$ is the reference dose of each heavy metal, $\mathrm{mg} \mathrm{kg}^{-1} \mathrm{day}^{-1}$, that a person may be exposed to per day either by ingestion or dermal contact in his entire lifetime without any harm. RfDs ( $\mathrm{mg} \mathrm{kg}^{-1} \mathrm{day}^{-1}$ ) by ingestion for copper, cadmium, lead and zinc, are $0.04,0.001,0.0035$ and 0.300 , respectively $[63,69,70]$. Similarly, the RfDs $\left(\mathrm{mg} \mathrm{kg}^{-1} \mathrm{day}^{-1}\right)$ by dermal contact for copper, cadmium, lead and zinc are 0.012 , $0.00001,0.000525$ and 0.06 , correspondingly $[71,72]$. No HQ was computed for iron by the two pathways because of non-availability of RfD. Hazard index, HI, the sum of HQs for all the non-carcinogenic heavy metals of concern, was calculated as shown in Equation (5) [68,73].

\subsubsection{Carcinogenic Risk Assessment}

Carcinogenic risk, otherwise known as cancer risk (CR), is defined as the incremental risk of a person having cancer over a lifetime by means of an exposure to a carcinogenic substance such as heavy metals. It is usually calculated by multiplying ADD with slope factor (SF) for each heavy metal of interest [74]. In this study, slope factors by oral intake or ingestion were only found for lead $\left(8.50 \times 10^{-3} \mathrm{mg} \mathrm{kg}^{-1} \mathrm{day}^{-1}\right)$ and cadmium $\left(0.38 \mathrm{mg} \mathrm{kg}^{-1} \mathrm{day}^{-1}\right)$. Hence, CR was computed for those two elements by the ingestion pathway. Risk index (RI) is also determined by the addition of cancer risks for all the metals of interest, as demonstrated in Equations (6) and (7) $[63,68,70,71,75,76]$.

$$
\begin{gathered}
\mathrm{CR}=\mathrm{ADD} \times \mathrm{SF} \\
\mathrm{RI}=\Sigma \mathrm{CR}
\end{gathered}
$$

\subsection{Statistical Treatment of Data}

Statistical analysis of data was accomplished using IBM SPSS Statistics version 25. Amongst the sets of analyses performed were t-test used for determining variations among pairs of treatments, one-way analysis of variance (ANOVA) and Pearson correlation.

\section{Results}

\subsection{Levels of Heavy Metals in the Wastewater and River Water Samples}

Table 1 shows the levels of heavy metals recorded in the wastewater and river water samples collected from the three wastewater treatment facilities. $\mathrm{Zn}$ and $\mathrm{Pb}$ were below detection in all the study sites. Fe was detected throughout while $\mathrm{Cu}$ and $\mathrm{Cd}$ were only observed in some months of the study period. Concentrations of $\mathrm{Cu}, \mathrm{Cd}$ and $\mathrm{Fe}$ in this study varied: $<\mathrm{DL}-0.07 \mathrm{mg} \mathrm{L}^{-1},<\mathrm{DL}-0.13 \mathrm{mg}$ $\mathrm{L}^{-1}$, and $<\mathrm{DL}-6.588 \mathrm{mg} \mathrm{L}^{-1}$ in the influents; $<\mathrm{DL}-0.06 \mathrm{mg} \mathrm{L}^{-1},<\mathrm{DL}-0.13 \mathrm{mg} \mathrm{L}^{-1}$ and $<\mathrm{DL}-0.636 \mathrm{mg}$ $\mathrm{L}^{-1}$ in the effluents, $<\mathrm{DL}-0.06 \mathrm{mg} \mathrm{L}^{-1},<\mathrm{DL}-0.13 \mathrm{mg} \mathrm{L}^{-1}$, and $<\mathrm{DL}-0.878 \mathrm{mg} \mathrm{L}^{-1}$ in the river water samples. WWTP-A recorded the highest levels of $\mathrm{Cu}$ in the river water samples $\left(0.06 \mathrm{mg} \mathrm{L}^{-1}\right), \mathrm{Cd}$ in the effluents $\left(0.13 \mathrm{mg} \mathrm{L}^{-1}\right)$ and Fe in the influents $\left(6.588 \mathrm{mg} \mathrm{L}^{-1}\right)$. Likewise, the maximum concentrations of $0.07 \mathrm{mg} \mathrm{L}^{-1}$ and $0.636 \mathrm{mg} \mathrm{L}^{-1}$ were recorded at WWTP-B for $\mathrm{Cu}$ in the influents and Fe in the effluents, 
correspondingly. At WWTP-C, $0.06 \mathrm{mg} \mathrm{L}^{-1}$ was obtained as the highest value of $\mathrm{Cu}$ in the effluents, while $\mathrm{mg} \cdot \mathrm{L}^{-1}$ and $0.13 \mathrm{mg} \mathrm{L}{ }^{-1}$ were the maximum concentrations for $\mathrm{Cd}$ in both the influents and river water samples across the study sites and their aqueous matrices. As earlier indicated, no samples were collected in the upstream of WWTP-C because of inaccessibility, and effluent at WWTP-B is not discharged into any river but channelled to a golf course for irrigation and a construction site. Of all the five metallic elements determined, Fe recorded highest values in the influents $\left(6.588 \mathrm{mg} \mathrm{L}^{-1}\right)$, effluents $\left(0.636 \mathrm{mg} \mathrm{L}^{-1}\right)$, upstream $\left(0.878 \mathrm{mg} \mathrm{L}^{-1}\right)$ and downstream $\left(0.711 \mathrm{mg} \mathrm{L}^{-1}\right)$.

Table 1. Levels of heavy metals in wastewater and surface water from WWTP-A, B and C $\left(\mathrm{mg} \cdot \mathrm{L}^{-1}\right)$.

\begin{tabular}{|c|c|c|c|c|c|c|c|}
\hline Plant & Location & & $\mathrm{Zn}\left(\mathrm{mg} \mathrm{L}^{-1}\right)$ & $\mathrm{Cu}\left(\mathrm{mg} \mathrm{L}^{-1}\right)$ & $C d\left(\mathrm{mg} \mathrm{L}^{-1}\right)$ & $\mathrm{Fe}\left(\mathrm{mg} \mathrm{L}^{-1}\right)$ & $\mathrm{Pb}\left(\mathrm{mg} \mathrm{L}^{-1}\right)$ \\
\hline & \multirow{2}{*}{ Influent } & Mean & $<\mathrm{DL}$ & $0.04 \pm 0.003$ & $0.11 \pm 0.001$ & $2.077 \pm 0.89$ & $<\mathrm{DL}$ \\
\hline & & Range & $<\mathrm{DL}$ & $<\mathrm{DL}-0.05$ & $<\mathrm{DL}-0.12$ & $<\mathrm{DL}-6.588$ & $<\mathrm{DL}$ \\
\hline & \multirow[t]{3}{*}{ Effluent } & Mean & $<\mathrm{DL}$ & $0.04 \pm 0.002$ & $0.11 \pm 0.001$ & $0.28 \pm 0.027$ & $<\mathrm{DL}$ \\
\hline & & Range & $<\mathrm{DL}$ & $<$ DL-0.05 & $<\mathrm{DL}-0.13$ & $<\mathrm{DL}-0.33$ & $<\mathrm{DL}$ \\
\hline & & \% RE & N/A & 0 & 0 & 86.6 & N/A \\
\hline & \multirow[t]{2}{*}{ Upstream } & Mean & $<\mathrm{DL}$ & $0.04 \pm 0.004$ & $0.11 \pm 0.001$ & $0.648 \pm 0.076$ & $<\mathrm{DL}$ \\
\hline & & Range & $<\mathrm{DL}$ & $<\mathrm{DL}-0.06$ & $<\mathrm{DL}-0.12$ & $<\mathrm{DL}-0.878$ & $<\mathrm{DL}$ \\
\hline & \multirow[t]{2}{*}{ Downstream } & Mean & $<\mathrm{DL}$ & $0.05 \pm 0.019$ & $0.11 \pm 0.042$ & $0.594 \pm 0.116$ & $<\mathrm{DL}$ \\
\hline & & Range & $<\mathrm{DL}$ & $<\mathrm{DL}-0.06$ & $<\mathrm{DL}-0.13$ & $<$ DL-0.711 & $<\mathrm{DL}$ \\
\hline \multirow[t]{5}{*}{ WWTP-B } & \multirow[t]{2}{*}{ Influent } & Mean & $<\mathrm{DL}$ & $0.05 \pm 0.012$ & $0.11 \pm 0.002$ & $0.959 \pm 0.134$ & $<\mathrm{DL}$ \\
\hline & & Range & $<\mathrm{DL}$ & $<\mathrm{DL}-0.07$ & $<\mathrm{DL}-0.13$ & $<\mathrm{DL}-2.257$ & $<\mathrm{DL}$ \\
\hline & \multirow[t]{3}{*}{ Effluent } & Mean & $<\mathrm{DL}$ & $0.04 \pm 0.003$ & $0.11 \pm 0.002$ & $0.463 \pm 0.084$ & $<\mathrm{DL}$ \\
\hline & & Range & $<\mathrm{DL}$ & $<\mathrm{DL}-0.05$ & $<\mathrm{DL}-0.12$ & $<\mathrm{DL}-0.636$ & $<\mathrm{DL}$ \\
\hline & & \% RE & N/A & 23.4 & 0 & 34.7 & N/A \\
\hline \multirow{7}{*}{ WWTP-C } & \multirow[t]{2}{*}{ Influent } & Mean & $<\mathrm{DL}$ & $0.04 \pm 0.003$ & $0.12 \pm 0.002$ & $0.887 \pm 0.159$ & $<\mathrm{DL}$ \\
\hline & & Range & $<\mathrm{DL}$ & $<\mathrm{DL}-0.05$ & $<\mathrm{DL}-0.13$ & $<\mathrm{DL}-1.806$ & $<\mathrm{DL}$ \\
\hline & \multirow[t]{3}{*}{ Effluent } & Mean & $<\mathrm{DL}$ & $0.04 \pm 0.002$ & $0.12 \pm 0.002$ & $0.382 \pm 0.028$ & $<\mathrm{DL}$ \\
\hline & & Range & $<\mathrm{DL}$ & $<\mathrm{DL}-0.06$ & $<\mathrm{DL}-0.13$ & $<\mathrm{DL}-0.557$ & $<\mathrm{DL}$ \\
\hline & & $\%$ RE & $\mathrm{N} / \mathrm{A}$ & 0 & 0 & 56.9 & $\mathrm{~N} / \mathrm{A}$ \\
\hline & \multirow[t]{2}{*}{ Downstream } & Mean & $<\mathrm{DL}$ & $0.04 \pm 0.002$ & $0.12 \pm 0.001$ & $0.42 \pm 0.088$ & $<\mathrm{DL}$ \\
\hline & & Range & $<\mathrm{DL}$ & $<$ DL- -0.05 & $<\mathrm{DL}-0.13$ & $<\mathrm{DL}-0.61$ & $<\mathrm{DL}$ \\
\hline
\end{tabular}

$<$ DL: Below Detection Limit; \%RE: Percentage removal efficiency; N/A: Not applicable.

$\mathrm{Cu}$ and Fe were below the maximum limits of $0.2 \mathrm{mg} \mathrm{L}^{-1}$ and $5 \mathrm{mg} \mathrm{L}^{-1}$ in the effluents from the three plants $[77,78]$, and fell short of the target values of $2 \mathrm{mg} \mathrm{L}^{-1}$ and $1 \mathrm{mg} \mathrm{L}^{-1}$ in the downstream and upstream of the receiving waterbodies in WWTP-A and WWTP-C, correspondingly (Table 2) [25,79-81]. The mean concentrations of $0.11 \mathrm{mg} \mathrm{L}^{-1}, 0.11 \mathrm{mg}^{-1}$ and $0.12 \mathrm{mg} \mathrm{L}^{-1}$ recorded for $\mathrm{Cd}$ in the effluent samples collected from WWTP-A, WWTP-B and WWTP-C were above the threshold value of $0.01 \mathrm{mg}$ $\mathrm{L}^{-1}$ recommended for domestic wastewater meant to be discharged into environmental water [82]. In like manner, the mean concentrations of $0.11 \mathrm{mg} \mathrm{L}^{-1}$ obtained for $\mathrm{Cd}$ in the upstream of the receiving waterbody at WWTP-A, and the levels found in the downstreams of WWTP-A and WWTP-C, were all higher than the recommended limit of $0.003 \mathrm{mg} \mathrm{L}^{-1}$ (Table S1) [79,83]. Overall, the heavy metal dominance in the aqueous media of the study sites follows this order: $\mathrm{Fe}>\mathrm{Cd}>\mathrm{Cu}$. The concentrations of $\mathrm{Cu}$ in the effluents in this study are comparable to those reported by Okonkwo and Mothiba [84] $\left(2 \times 10^{-3}-3 \times 10^{-3} \mathrm{mg} \mathrm{L}^{-1}\right)$, [36] $\left(6.99 \times 10^{-3}\right.$ to $\left.0.305 \mathrm{mg} \mathrm{L}^{-1}\right)$, Nyamukamba et al. [37] (0.054 to $0.152 \mathrm{mg}$ $\left.\mathrm{L}^{-1}\right)$, Wilderer and Kolb [85] in Munich, Germany $\left(0.2 \mathrm{mg} \mathrm{L}^{-1}\right)$, and Zhou et al. [42] (0.01-0.36 $\left.\mathrm{mg} \mathrm{L}^{-1}\right)$ in China. For Cd, Fatoki et al. [86] and Awofolu et al. [87] had results similar to those obtained in the present study from the Umtata and Tyume Rivers in the same province, respectively. ENVIRODAT [88] and Du et al. [5] also documented Cd ranging from $<1 \times 10^{-4}$ to $0.112 \mathrm{mg} \mathrm{L}^{-1}$ in Alberta surface water; from $7.0 \times 10^{-3}$ to $7.8 \times 10^{-2} \mathrm{mg} \cdot \mathrm{L}^{-1}$ in the raw influent and from $<\mathrm{DL}$ to $5.6 \times 10^{-2} \mathrm{mg} \mathrm{L}^{-1}$ in the effluent of municipal wastewater in Heilongjiang Province, China. However, lower concentrations of Cd were obtained in other river systems receiving wastewater effluents in Cape Town, South Africa $\left(9 \times 10^{-5}\right.$ to $\left.1.48 \times 10^{-2} \mathrm{mg} \mathrm{L}^{-1}\right)$ (Olujimi et al., [36]. Extremely high result $\left(5 \mathrm{mg} \mathrm{L}^{-1}\right)$ for Cd was also documented by Teijon et al. [89] in the treated wastewater at Depurbaix facility in Spain. Our findings 
on Fe agree with those reported by Nyamukamba et al. [37], in which the element was detected in the range $0.105-0.396 \mathrm{mg} \mathrm{L}^{-1}$ in water samples. This is also consistent with the Fe values reported by Zhou et al. [90] for rivers and lakes in Africa $\left(2.013 \pm 0.475 \mathrm{mg} \cdot \mathrm{L}^{-1}\right)$, Asia $\left(3.153 \pm 2.376 \mathrm{mg} \cdot \mathrm{L}^{-1}\right) \mathrm{and}$ South America $\left(1.204 \pm 1.561 \mathrm{mg} \cdot \mathrm{L}^{-1}\right)$.

Table 2. Guidelines for metallic element in surface water, effluent and sewage sludge.

\begin{tabular}{cccccc}
\hline Metals & $\begin{array}{c}\text { Surface Water } \\
\left(\mathrm{mg} \mathrm{L}^{-1}\right)\end{array}$ & \multicolumn{2}{c}{ Effluent $\left(\mathrm{mg} \mathrm{L}^{-\mathbf{1}}\right)$} & \multicolumn{2}{c}{ Sludge $\left(\mathrm{mg} \mathrm{kg}^{-\mathbf{1}}\right)$} \\
& WHO [84] & $\begin{array}{c}\text { DWAF, [82]; } \\
\text { Shomar et al. [78] }\end{array}$ & $\begin{array}{c}\text { US EPA, [79]; } \\
\text { Shomar et al. [78] }\end{array}$ & DWAF [91] & US EPA [80] \\
\hline $\mathbf{C u}$ & 2 & - & 0.2 & 450 & 1500 \\
$\mathbf{C d}$ & 0.003 & -.01 & - & 5 & 39 \\
$\mathbf{F e}$ & - & - & 5 & - & - \\
$\mathbf{P b}$ & 0.01 & - & 0.05 & 150 & 300 \\
$\mathbf{Z n}$ & - & - & 2 & 700 & 2800 \\
\hline
\end{tabular}

\subsection{Levels of Heavy Metals in the Sludge}

Of the five metallic elements determined in this study, the concentration of zinc in all the sludge samples from the three treatment plants was below the detection limit ( $<\mathrm{DL})$. In the same vein, $\mathrm{Pb}$ was below detection at WWTP-B but was found in the other two treatment facilities, as shown in Table 3. $\mathrm{Cu}, \mathrm{Cd}, \mathrm{Fe}$ and $\mathrm{Pb}$ ranged from $<\mathrm{DL}$ to $1.17 \mathrm{mg} \mathrm{kg}^{-1},<\mathrm{DL}$ to $0.14 \mathrm{mg} \mathrm{kg}^{-1}, 28$ to $70 \mathrm{mg} \mathrm{kg}^{-1}$, and $<\mathrm{DL}$ to $0.099 \mathrm{mg} \mathrm{kg}^{-1}$, respectively. Maximum levels of $\mathrm{Cu}, \mathrm{Cd}$ and $\mathrm{Pb}$ were obtained from $\mathrm{WWTP}-\mathrm{A}$, whereas the highest concentration of Fe was detected at WWTP-C (Table 3). The order of dominance in all the locations is as follows: $\mathrm{Fe}>\mathrm{Cu}>\mathrm{Cd}>\mathrm{Pb}$, showing $\mathrm{Fe}$ as the metal with highest concentrations throughout and $\mathrm{Pb}$ as the least. The levels of $\mathrm{Cu}, \mathrm{Cd}, \mathrm{Pb}$ and $\mathrm{Zn}$ in this study were generally below the recommended limits of $1500 \mathrm{mg} \mathrm{kg}^{-1}, 39 \mathrm{mg} \mathrm{kg}^{-1}, 300 \mathrm{mg} \mathrm{kg}^{-1}$ and $2800 \mathrm{mg} \mathrm{kg}^{-1}$, respectively, for sludge intended for use in agriculture in the USA [92]; and the maximum permissible levels of $450 \mathrm{mg} \mathrm{kg}^{-1}, 5 \mathrm{mg} \mathrm{kg}^{-1}, 150 \mathrm{mg} \mathrm{kg}^{-1}$ and $700 \mathrm{mg} \mathrm{kg}^{-1}$ in South Africa (Table 2). However, there is no target limit for Fe in sludge, possibly because it is an essential element [91]. The levels of $\mathrm{Cu}, \mathrm{Cd}$, $\mathrm{Fe}$ and $\mathrm{Pb}$ in the sewage sludge samples in our study agree with other published reports in different regions of the world. For instance, Tiruneh et al. [93] reported values ranging from $0-96 \mathrm{mg} \mathrm{kg}^{-1}$ for $\mathrm{Pb}$ in sewage sludge samples collected from Swaziland (Tiruneh et al. [93], while Nyamukamba et al. [37] reported values below detection limits for $\mathrm{Pb}$ in all their sewage sludge samples. However, higher values in the range of $97.6-187.8 \mathrm{mg} \mathrm{kg}^{-1} ; 56.9-89.251 \mathrm{mg} \mathrm{kg}^{-1} ; 11-110 \mathrm{mg} \mathrm{kg}^{-1}$ and $69-365 \mathrm{mg}$ $\mathrm{kg}^{-1}$ were documented for $\mathrm{Pb}$ in Poland [8], Shanghai City, China [4], Sweden [94] and other location in South Africa [80].

Table 3. Levels of heavy metals in sludge samples from WWTP-A, B and C $\left(\mathrm{mg} \mathrm{kg}^{-1}\right)$.

\begin{tabular}{|c|c|c|c|c|c|c|}
\hline Plant & & $\mathrm{Zn}\left(\mathrm{mg} \mathrm{kg}{ }^{-1}\right)$ & $\mathrm{Cu}\left(\mathrm{mg} \mathrm{kg}{ }^{-1}\right)$ & $\mathrm{Cd}\left(\mathrm{mg} \mathrm{kg}^{-1}\right)$ & $\mathrm{Fe}\left(\mathrm{mg} \mathrm{kg}^{-1}\right)$ & $\mathrm{Pb}\left(\mathrm{mg} \mathrm{kg}^{-1}\right)$ \\
\hline \multirow[t]{2}{*}{ WWTP-A } & Mean & $<\mathrm{DL}$ & $0.74 \pm 0.214$ & $0.13 \pm 0.003$ & $39 \pm 4.125$ & $0.099 \pm 0.037$ \\
\hline & Range & $<\mathrm{DL}$ & 0.43-1.17 & $<\mathrm{DL}-0.14$ & 29-49 & $<$ DL-0.099 \\
\hline \multirow[t]{2}{*}{ WWTP-B } & Mean & $<\mathrm{DL}$ & $0.44 \pm 0.25$ & $0.1 \pm 0.002$ & $40 \pm 9.48$ & $<\mathrm{DL}$ \\
\hline & Range & $<\mathrm{DL}$ & $<\mathrm{DL}-0.66$ & $<\mathrm{DL}-0.12$ & 28-49 & $<\mathrm{DL}$ \\
\hline \multirow[t]{2}{*}{ WWTP-C } & Mean & $<\mathrm{DL}$ & $0.53 \pm 0.101$ & $0.5 \pm 0.001$ & $45 \pm 2.335$ & $0.065 \pm 0.02$ \\
\hline & Range & $<\mathrm{DL}$ & $0.36-0.64$ & $<\mathrm{DL}-0.13$ & $29-70$ & $<\mathrm{DL}-0.065$ \\
\hline
\end{tabular}

$<$ DL: Below Detection Limit.

Similarly, the levels of copper in sludge samples in the present study were much lower compared to those reported by SEPA [94] from Sweden (78-1800 mg kg-1), Tiruneh et al. [93] from Swaziland (103-696 mg kg-1), Tytla [8] from Poland (104-194 $\mathrm{mg} \mathrm{kg}^{-1}$ ), Dai et al. [4] from Shanghai City, China (156.40-3873 $\mathrm{mg} \mathrm{kg}^{-1}$ ), Shamuyarira and Gumbo [35] from sewage facilities in Limpopo region (263.68 to $626.00 \mathrm{mg} \mathrm{kg}^{-1}$ ), and Morrison et al. [95] from other locations in South Africa (245 $\mathrm{mg} \mathrm{kg}^{-1}$ to $441 \mathrm{mg}$ $\mathrm{kg}^{-1}$ ). In the same vein, the concentration of $\mathrm{Cd}$ in this study was very low compared to results from 
similar studies in many places, including the sewage sludge findings published by Tytla [8] in Poland (2.7-4.1 $\left.\mathrm{mg} \mathrm{kg}^{-1}\right)$, Dai et al. [4] in Shanghai City, China (11.9-81.2 $\left.\mathrm{mg} \mathrm{kg}^{-1}\right)$, SEPA, [94] in Sweden (0.58-11 $\mathrm{mg} \mathrm{kg}^{-1}$ d.m.), and Shamuyarira and Gumbo [35] in the Limpopo Province, South Africa (3.10 $\mathrm{mg} \mathrm{kg}^{-1} \mathrm{~d} . \mathrm{m}$.), where mining activities are daily carried out compared to the semi-urban sites in the present study [35]. However, Fe in this study is within the range of values reported in Swaziland (8.559-36.188 $\mathrm{mg} \mathrm{kg}^{-1}$ ) by Tiruneh et al. [93] but lower than those from Sweden (4400-150,000 mg kg-1 d.m.) SEPA, [94].

\subsection{Percentage Removal of Heavy Metals in the Three WWTPS}

The performances of the various technologies in use at the three WWTPs were assessed by calculating the percentage at which they remove those metals of interest in this study. $\mathrm{Zn}$ and $\mathrm{Pb}$ were left out in this assessment since they were generally below detection limits in all the plants under investigation. In WWTP-A, Cu and Cd were obviously not removed at all because the amount that entered the plant remained unchanged even after the treatment. Hence, the removal efficiencies of the plant with respect to the two heavy metals were $0 \%$. However, the removal of Fe was very successful at $86.6 \%$, showing that the plant has a good capacity to remove this element from the influent wastewater. Similarly, removal efficiencies of WWTP-B for $\mathrm{Cu}, \mathrm{Cd}$, and Fe were $23.4 \%, 0 \%$, and 34.7\%, respectively. At WWTP-C, Cu, Cd and Fe were removed at $0 \%, 0 \%$ and $56.9 \%$ efficiencies, respectively (Table 1 ). This shows that none of the three sewage treatment plants could remove $\mathrm{Cu}$ and $\mathrm{Cd}$ substantially; however, they all demonstrated capacities for the removal of Fe in this order: WWTP-A > WWTP-C $>$ WWTP-B.

\subsection{Health Risk Assessment}

The probable non-carcinogenic and carcinogenic risks by ingestion with respect to sewage sludge analysed in this study are presented in Table 4. HQs obtained for both adults and children categories with respect to $\mathrm{Cu}, \mathrm{Cd}$ and $\mathrm{Pb}$ were generally in the range of $1.49 \times 10^{-5}$ for adults (WWTP-B) to $1.62 \times 10^{-3}$ for children (WWTP-A), with Cadmium having the highest. Similarly, HI varied between $1.52 \times 10^{-4}$ for adults (WWTP-B) and $2.18 \times 10^{-3}$ for children (WWTP-A). Table 5 also presents the potential health risks by dermal contact owing to exposure to the sewage sludge from any of the treatment works under study. The HQs for the two categories of people across the three treatment facilities ranged from $1.98 \times 10^{-7}$ for adults (WWTP-B) to $3.23 \times 10^{-4}$ for children (WWTP-A), while HI also varied from $5.49 \times 10^{-5}$ for adults in WWTP-B to $3.29 \times 10^{-4}$ for children in WWTP-A.

Table 4. Carcinogenic and non-carcinogenic risks assessment by ingestion in sewage sludge.

\begin{tabular}{|c|c|c|c|c|c|c|c|}
\hline Location & Category & Risk Type & $\mathrm{Cu}$ & $\mathrm{Cd}$ & $\mathbf{P b}$ & HI & RI \\
\hline \multirow{4}{*}{ WWTP-A } & \multirow{2}{*}{ Adults } & HO & $2.54 \times 10^{-5}$ & $1.85 \times 10^{-4}$ & $3.91 \times 10^{-5}$ & $2.49 \times 10^{-4}$ & - \\
\hline & & CR & - & $3.01 \times 10^{-8}$ & $4.99 \times 10^{-10}$ & - & $3.06 \times 10^{-8}$ \\
\hline & \multirow{2}{*}{ Children } & HQ & $2.22 \times 10^{-4}$ & $1.62 \times 10^{-3}$ & $3.43 \times 10^{-4}$ & $2.18 \times 10^{-3}$ & - \\
\hline & & CR & - & $5.27 \times 10^{-8}$ & $8.73 \times 10^{-10}$ & - & $5.36 \times 10^{-8}$ \\
\hline \multirow{4}{*}{ WWTP-B } & \multirow{2}{*}{ Adults } & HQ & $1.49 \times 10^{-5}$ & $1.37 \times 10^{-4}$ & - & $1.52 \times 10^{-4}$ & - \\
\hline & & $\widehat{C R}$ & - & $2.23 \times 10^{-8}$ & - & - & $2.23 \times 10^{-8}$ \\
\hline & \multirow{2}{*}{ Children } & HQ & $1.2 \times 10^{-4}$ & $1.2 \times 10^{-3}$ & - & $1.33 \times 10^{-3}$ & - \\
\hline & & $\widehat{C R}$ & - & $3.90 \times 10^{-8}$ & - & - & $3.9 \times 10^{-8}$ \\
\hline \multirow{4}{*}{ WWTP-C } & \multirow[b]{2}{*}{ Adults } & HQ & $1.82 \times 10^{-5}$ & $1.71 \times 10^{-4}$ & $2.54 \times 10^{-5}$ & $2.15 \times 10^{-4}$ & - \\
\hline & & $\mathrm{CR}$ & - & $2.79 \times 10^{-8}$ & $3.24 \times 10^{-10}$ & - & $2.82 \times 10^{-8}$ \\
\hline & \multirow{2}{*}{ Children } & HQ & $1.59 \times 10^{-4}$ & $1.5 \times 10^{-3}$ & $2.23 \times 10^{-4}$ & $1.88 \times 10^{-3}$ & - \\
\hline & & CR & - & $4.88 \times 10^{-8}$ & $5.68 \times 10^{-10}$ & - & $4.94 \times 10^{-8}$ \\
\hline
\end{tabular}

HQ: Hazard Quotient; CR: Carcinogenic Risk; HI: Hazard Index; RI: Risk Index.

In the same vein, Table 4 shows the results for the carcinogenic risk assessment by ingestion in all the study locations. Available slope factors were only for $\mathrm{Cd}$ and $\mathrm{Pb}$, hence the results captured in the table were simply for these two heavy metals. Moreover, since Pb concentrations in WWTP-B and WWTP-C were all below the detection limit, cancer risk for Pb was only evaluated at the WWTP-A 
where the level was significant. Overall, carcinogenic risk (CR) for Cd, both for adults and children in the three sites, ranged between $2.23 \times 10^{-8}(\mathrm{WWTP}-\mathrm{B})$ and $5.27 \times 10^{-8}$ (WWTP-A). Likewise, CR for $\mathrm{Pb}$ in WWTP-A ranged between $4.99 \times 10^{-10}$ (adults) and $8.73 \times 10^{-10}$ (children). The risk indices (RI), which were the sum of CRs in each category and individual plant, varied between $2.23 \times 10^{-8}$ (WWTP-B) and $5.36 \times 10^{-8}($ WWTP-A).

Table 5. Non-carcinogenic risk assessment by dermal contact in the sewage sludge.

\begin{tabular}{cccccc}
\hline Location & Category & HQ $_{\mathbf{C u}}$ & HQ $_{\mathbf{C d}}$ & HQ $_{\mathbf{P b}}$ & HI \\
\hline \multirow{2}{*}{ WWTP-A } & Adults & $3.38 \times 10^{-7}$ & $7.38 \times 10^{-5}$ & $1.04 \times 10^{-6}$ & $7.52 \times 10^{-5}$ \\
& Children & $1.48 \times 10^{-6}$ & $3.23 \times 10^{-4}$ & $4.56 \times 10^{-6}$ & $3.29 \times 10^{-4}$ \\
\hline \multirow{2}{*}{ WWTP-B } & Adults & $1.98 \times 10^{-7}$ & $5.47 \times 10^{-5}$ & - & $5.49 \times 10^{-5}$ \\
& Children & $8.65 \times 10^{-7}$ & $2.39 \times 10^{-4}$ & - & $2.4 \times 10^{-4}$ \\
\hline \multirow{2}{*}{ WWTP-C } & Adults & $2.41 \times 10^{-7}$ & $6.83 \times 10^{-5}$ & $6.77 \times 10^{-7}$ & $6.92 \times 10^{-5}$ \\
& Children & $1.06 \times 10^{-6}$ & $2.99 \times 10^{-4}$ & $2.96 \times 10^{-6}$ & $3.03 \times 10^{-4}$ \\
\hline
\end{tabular}

HQ: Hazard Quotient; HI: Hazard Index.

\subsection{Statistical Analysis}

In the statistical correlations among the heavy metals in the wastewater and river water samples across the three study locations, Cd exhibited a negative correlation with $\mathrm{Fe}(\mathrm{r}=-0.86$, at $p<0.01)$, and a positive relationship with copper $(\mathrm{r}=-0.94$ at $p<0.01)$. There was also a negative correlation between $\mathrm{Cu}$ and $\mathrm{Fe}(\mathrm{r}=-0.67$ at $p<0.01)$, as shown in Supplementary Tables S1 and S2. Similarly, in the sludge samples, $\mathrm{Pb}$ showed a positive correlation with $\mathrm{Zn}(\mathrm{r}=0.58$ at $p<0.01)$ and a negative correlation with $\mathrm{Cd}(\mathrm{r}=-0.48$ at $p<0.01)$. The positive correlations obtained between some metallic elements may prove that they may have similar accumulation behaviours or emanate from the same environmental sources of pollution $[8,25]$. The ANOVA data revealed no significant variation among the heavy metals being studied except for $\mathrm{Cu}$, which demonstrated a substantial statistical difference between WWTP-A and WWTP-B (F=4.1, $\mathrm{r}=0.03)$ as presented in Supplementary Tables S3 and S4. This can be related to the wide margin observed in the mean concentrations recorded for the sludge samples in the two sewage plants, i.e. $0.74 \pm 0.214 \mathrm{mg} \mathrm{kg}^{-1}$ (WWTP-A) and $0.44 \pm 0.25 \mathrm{mg} \mathrm{kg}^{-1}$ (WWTP-B), although they were both within acceptable limits (Table 3).

\section{Discussion}

\subsection{Levels of Heavy Metals in the Wastewater, River Water and Sludge Samples}

The concentrations of the five heavy metals $(\mathrm{Zn}, \mathrm{Fe}, \mathrm{Cd}, \mathrm{Cu}$ and $\mathrm{Pb})$ recorded in the sewage sludge samples in this study were mostly higher than those in the wastewater and river water samples. This is not unusual because $80-90 \%$ of heavy metals in influent water are known to accumulate in sewage sludge. That is why the reuse of sludge is considered as a way of polluting the environment a second time [8]. The use of sewage sludge as landfill cover, soil conditioner or fertilizer in farms, or for once-off high rate application to exposed mine tailings, has been on the increase in recent times. Thus, reducing levels of heavy metals to the barest minimum before such applications is vital [96]. Similarly, wastewater requires adequate treatment to keep the contaminants below hazardous levels before considering irrigation as a way of safe disposal [35,97]. Hussain et al. [98], reported the possibility of accumulation of heavy metals and other macro- and micro-pollutants in soil and vegetables irrigated with partially treated or untreated wastewater.

The levels of zinc were below detection in sludge and aqueous samples across the study period and sites. Soluble zinc is usually very abundant at slightly acidic $\mathrm{pH}$ under a well-oxidized environment, but less soluble, immobile and less bioavailable when the $\mathrm{pH}$ is basic [93]. The influents, effluents and river waters in this study were all in the $\mathrm{pH}$ range of 7.01-8.98, as previously reported [44]. No known disease is associated with a high level of zinc in drinking water; hence, no health-based 
guideline value has been set for this metallic element [83]. In this study, $\mathrm{Pb}$ was below detection in all aqueous samples but was detected only once in the sludge collected from each of the WWTP-A $\left(0.099 \mathrm{mg} \mathrm{kg}^{-1}\right)$ and WWTP-C $\left(0.065 \mathrm{mg} \mathrm{kg}^{-1}\right)$ (Table 1 and Supplementary Table S5), even though the amounts found were all below hazardous levels to human health [77,91]. The low levels of $\mathrm{Pb}$ in our study could be linked with the recent phasing out of leaded fuels and lead-containing water pipes in the country, as vehicular emission accounts for a huge percentage of $\mathrm{Pb}$ in the environment $[26,99]$. This assertion is corroborated with the findings of Shamuyarira and Gumbo [35] in certain locations of Limpopo Province, South Africa. Although, $\mathrm{Pb}$ in its organic and inorganic forms is injurious to health, organometallic species (e.g., tetraethyl lead (TEL) contained in the leaded fuel) are more toxic, as they are more soluble and bioavailable in natural water than the inorganic compounds that are usually present in large quantity in the environment. TEL is considered even more toxic than its methylated counterparts. Notwithstanding, the inorganic lead (e.g., $\mathrm{Pb}$ in the mineral deposits) can also gain mobility and become more soluble under moderately low $\mathrm{pH}$ [100].

The concentrations of Fe in the sludge, wastewater and surface water samples from the three study locations in this study were tolerable. A high value of $6.588 \mathrm{mg} \mathrm{L}^{-1}$ was only found once in the effluent from WWTP-A in September but was well removed before discharge to the environment (Table 1 and Supplementary Table S6). Its detection in almost all the study locations and months proved that it is actually a very abundant metal in the environment. In view of the importance of iron as an essential element for the growth and survival of plants, animals and humans, WHO does not have any health-based guideline for Fe in drinking water. Notwithstanding, water containing Fe at levels above $0.3 \mathrm{mg} \mathrm{L}^{-1}$ can stain laundry and plumbing fittings [83,90]. Major anthropogenic sources of iron in environmental waters are mining activities [101]. However, in this study, levels of Fe in solid and aqueous samples could be linked to eroding roofing sheets, use of steel and iron cookware, and other related household products, besides natural deposits [102].

Cadmium was only detected in two months of the summer season, which is usually characterized by heavy rainfall in all the aqueous and solid samples in this study. This agrees with the findings of Edokpayi et al. [101], who reported higher values of Cd in the wet season, thus suggesting the possibility of stormwater drains and runoffs from nearby roads and agricultural farms entering the sewage plants $[35,101]$. The levels in the sludge pose no threat to humans and the environment, especially if considered for use as soil conditioner or fertilizer in farming, whereas the mean concentrations of $0.11 \mathrm{mg}$ $\mathrm{L}^{-1}, 0.11 \mathrm{mg} \mathrm{L}^{-1}$ and $0.12 \mathrm{mg} \mathrm{L}^{-1}$ recorded in the effluent samples collected from WWTP-A, WWTP-B and WWTP-C (Table 1 and Supplementary Tables S6-S8) were all above the threshold values of $0.01 \mathrm{mg}$ $\mathrm{L}^{-1}$ recommended for domestic wastewater meant to be discharged into environmental water $[78,82]$. Therefore, using them for watering irrigation and/or livestock farmlands is not encouraged [36]. In like manner, the mean concentrations determined in the upstream and downstream of WWTP-A and WWTP-C were higher than the recommended limit of $0.005 \mathrm{mg} \mathrm{L}^{-1}$ (Table 2) [79], and therefore raise a huge concern. This could be linked with good solubility of cadmium in water, which makes it more hazardous and more bioavailable for humans, plants and animals, thereby signalling danger along the food chain [103]. Overuse of chemical fertilizers, especially those containing phosphate, have also been identified as a major source of cadmium in the environment [26,104]. Previous findings showed that continuous use of sewage sludge on farmland or irrigation with wastewater rich in this hazardous metal, over the years, can result in high level of cadmium in crops grown on such land, thus affecting the quality of farm produce and posing risk to the health of users [102,105].

Cadmium gradually accumulates in soil or sediments overtime, and in bioconcentrate along food the chain, with humans being the final consumer. Considering its soil-to-plant transfer, cadmium is commonly found in vegetables and fruits. Therefore, food is considered as one of its major sources of daily exposure to the environment [83]. Moreover, low population of freshwater mussels has been attributed to the toxicity and transfer of cadmium along the food chain [26,104,106-108]. Other sources of cadmium include impurities in galvanized pipes, solders and other metal fittings, tobacco products, combustion of coal, incineration of sewage sludge, rechargeable batteries, detergents, body care 
products, plant pigments and alloys $[26,83,108,109]$. Cadmium accumulates primarily in soft tissues of the body, especially in the liver and kidney, and has a lengthy biological half-life of 10-35 years in humans $[83,93,110]$. Available evidence has shown that the metal is carcinogenic by inhalation, although no documentary evidence has proven its carcinogenicity by oral intake [83].

In like manner, $\mathrm{Cu}$ in this study was detected mostly in the peak of the summer season in the wastewater and surface water samples, suggesting runoffs especially from agricultural farms as the primary origin [111]. The concentrations were far below levels $\left(5 \mathrm{mg} \mathrm{L}^{-1}\right)$ at which water colour can be affected [21], and at which damage to some body organs including liver and kidney can occur (2 mg $\mathrm{L}^{-1}$ ) [84]. This agrees with previous studies reported in other locations in South Africa by Okonkwo and Mothiba [84] and Nyamukamba et al. [37]. Copper concentrations in this region can be linked with agricultural activities, which vary from one location to the other. Its occurrence in the aquatic system could be attributed to dissolution of copper minerals in algicides and insecticides, and corrosion of copper alloy pipes used for distribution of water [37]. Other sources of $\mathrm{Cu}$ in the environment include fuels and lubricants, copper-containing fungicides and larvicides, cleaning and personal care products, pigments, paints and copper mines [93,109].

\subsection{Removal Efficiency of the Three WWTPs for Heavy Metals}

The removal efficiency obtained from the three STPs (Sewage Treatment Plants) confirmed the earlier reports that most of the existing WWTPs in Africa and other regions of the world were not designed for the removal of many inorganic and organic pollutants of environmental and health concern. Thus, the river bodies into which the final effluents are discharged are at risk of gross pollution [46,112]. In a previous study, WWTP-A which utilizes activated sludge technology performed better in the removal of phthalate esters compared to WWTP-B and WWTP-C, which employ the use of an oxidation pond and biofilter, possibly because of its secondary clarifier, which other technologies do not have $[46,113]$.

The proportion of phthalate esters removed varied from 76.99-99.41\% in WWTP-A, $61.24-98.34 \%$ in WWTP-B, and 75.59-98.46\% in WWTP-C. Virtually all the phthalate ester congeners were well removed in the three treatment plants, with activated sludge treatment in WWTP-A being the best, followed by biofilter/trickling filter technology in WWTP-C, and oxidation pond in WWTP-B. Their removal efficiencies were linked to their high capacities to remove the suspended particles onto which most of these contaminants were adsorbed, hence increasing concentrations in the sewage sludge when settled. Another reason given for such reduction is volatilization of the lighter congeners during aeration and sludge dehydration $[48,114,115]$.

However, unlike the phthalate compounds, most heavy metals are non-volatile due to their hardness; volatilization may not play any tangible role in their removal, although they also have tendencies towards adsorption to the suspended solids, hence the reason for the high levels recorded in sludge samples compared to the aqueous ones. WWTP-A, WWTP-B and WWTP-C removed iron in this study at $86.6 \%, 34.7 \%$ and $56.9 \%$, respectively. Apart from Fe that was sufficiently removed, performance of the three plants at removing $\mathrm{Cd}$ and $\mathrm{Cu}$ was extremely poor, with WWTP-B recording the highest removal capacity of $34.7 \%$ for $\mathrm{Cu}$ (Table 1). The removal of iron in the three technologies was achieved by oxidation of $\mathrm{Fe}(\mathrm{II})$ via aeration and/or microorganisms (bacteria), through which soluble Fe ions were transformed into insoluble heavier ones, that eventually settle down as precipitate. This process is temperature dependent. Precipitation is usually followed by sedimentation in the secondary clarifier (for activated sludge), dredging (for oxidation pond) and filtration (for biofilter), respectively. The precipitates are then collected as part of the sewage sludge, depending on their particle density [116-118]. This shows that, in spite of the fact that the sewage treatment plants were not designed at inception for the removal of such pollutants, they can function efficiently in the removal of some organic micro pollutants compared to heavy metals. Hence, there is an urgent need to review their efficiencies, in order to safeguard the lives of rural dwellers who use these receiving waterbodies 
for their daily domestic needs, especially with respect to cadmium which was above the recommended limit in this study.

\section{Health Risk Assessment}

The HQs and HIs were all below the benchmark of 1.0 and so implied that non-carcinogenic risk to both adults and children in all the locations were negligible. Non-carcinogenic risk is considered high when it exceeds 4 , medium when it falls between 1 and 4 , low when it varies between 0.1 and 1 , and negligible if it goes below 0.1 . In this study, the values were generally lower than 0.1 , and this implies that no adverse health effects (non-carcinogenic) would occur $[25,63,68]$.

According to Li et al. [119], CR between $10^{-6}$ and $10^{-5}$ is considered a low risk, values between $10^{-5}$ and $5 \times 10^{-4}$ is regarded as medium risk, and values that ranged between $5 \times 10^{-4}$ and $10^{-3}$ show high risk. Any $\mathrm{CR}$ value above $10^{-3}$ is extremely high and requires urgent attention. Meanwhile in this study, the CR and RI obtained were all below $10^{-6}$, which suggest an extremely low risk with respect to the development of cancer in any person exposed to the metallic elements under investigation, and thus does not raise any alarm [120].

\section{Conclusions}

The assessment of efficiency in the operation of the three sewage treatment plants in this study revealed slight pollution. Of the five metallic contaminants analysed in the sewage sludge, zinc was below detection throughout, while $\mathrm{Pb}$ was only detected once in each of WWTP-A and WWTP-C. The other three metals of concern $(\mathrm{Cu}, \mathrm{Cd}$, and $\mathrm{Fe})$ were found in very low concentrations, below recommended limits. Similarly, in the aqueous samples, $\mathrm{Zn}$ and $\mathrm{Pb}$ were below detection limits at all the sampling points at the three wastewater treatment plants. However, Fe was found in tolerable amounts in all the plants under investigation, especially between September and December. Moreover, $\mathrm{Cu}$ and $\mathrm{Fe}$ in all the sampling locations were below detection, but $\mathrm{Cd}$, which was only detected in the summer season (January and December) in all the study locations, was above the permissible level in the effluent, upstream and downstream samples. With regard to removal capacities, the order of plants' efficiency is WWTP-A > WWTP-C > WWTPB, especially with respect to Fe which was removed in quantity. $\mathrm{Cd}$ and $\mathrm{Cu}$ were very poorly removed from the influent waters in all the STPs. The risk assessment results indicated that none of the five metallic elements poses any health hazard (carcinogenic or non-carcinogenic) to humans, by oral intake or by skin contact. This suggests that the level of contamination, even with respect to cadmium, was minimal. Notwithstanding, since heavy metals can bioaccumulate, efforts should be made to reduce their level as much as possible in the effluent and sludge being discharged to the environment, either directly or by means of re-application for irrigation and as soil conditioner, in order to ensure the safety of all consumers of products emanating from such usage. It is also necessary for government agencies saddled with the management of the STPs to consider new technologies with better capacities for removing these pollutants.

Supplementary Materials: The following are available online at http://www.mdpi.com/2073-4441/12/10/2746/s1, Table S1: Pearson correlations for heavy metals in wastewater and surface waters, Table S2: ANOVA for heavy metals in wastewater and surface waters, Table S3: Pearson correlations for heavy metals in Sludge, Table S4: ANOVA for heavy metals in sludge, Table S6: Levels of heavy metals in wastewater and water from WWTP-A (mg.L $\left.{ }^{-1}\right)$, Table S7: Levels of heavy metals in wastewater and water from WWTP-B (mg.L $\left.{ }^{-1}\right)$, Table S8: Levels of heavy metals in wastewater and water from WWTP-C (mg.L $\left.{ }^{-1}\right)$, Table S5: Levels of heavy metals in sludge samples $\left(\mathrm{mg}_{\mathrm{kg}}{ }^{-1}\right)$.

Author Contributions: Conceptualization, M.A.A. (Mojeed Adedoyin Agoro) and A.O.A.; methodology M.A.A. (Mojeed Adedoyin Agoro) and A.O.A.; validation, M.A.A. (Martins Ajibade Adefisoye); A.O.A.; and M.A.A. (Mojeed Adedoyin Agoro); formal analysis M.A.A. (Martins Ajibade Adefisoye) and A.O.A.; investigation, M.A.A. (Mojeed Adedoyin Agoro) and A.O.A.; resources, M.A.A. (Mojeed Adedoyin Agoro); A.O.A.; and M.A.A. (Martins Ajibade Adefisoye); data curation, M.A.A. (Martins Ajibade Adefisoye); A.O.A.; and M.A.A. (Mojeed Adedoyin Agoro); writing - original draft preparation, M.A.A. (Mojeed Adedoyin Agoro) and A.O.A.; writing-review and editing, M.A.A. (Martins Ajibade Adefisoye) and A.O.A.; visualization, M.A.A. (Mojeed Adedoyin Agoro); 
A.O.A.; and M.A.A. (Martins Ajibade Adefisoye); supervision, O.O.O.; funding acquisition, O.O.O. All authors have read and agreed to the published version of the manuscript.

Funding: We are grateful to the South Africa Medical Research Council and the National Research Foundation for financial support.

Conflicts of Interest: The authors declare no conflict of interest.

\section{References}

1. Boxall, A.B.; Kolpin, D.W.; Halling-Sørensen, B.; Tolls, J. Are veterinary medicines causing environmental risks? Environ. Sci. Technol. 2003, 37, 286A-294A. [CrossRef]

2. Cantinho, P.; Matos, M.; Trancoso, M.A.; Correia dos Santos, M.M. Behaviour and fate of metals in urban wastewater treatment plants: A review. Int. J. Environ. Sci. Technol. 2016, 13, 359-386. [CrossRef]

3. Chen, W.; Li, Y.; Chen, C.-E.; Sweetman, A.J.; Zhang, H.; Jones, K.C. DGT passive sampling for quantitative in situ measurements of compounds from household and personal care products in waters. Environ. Sci. Technol. 2017, 51, 13274-13281. [CrossRef]

4. Dai, J.; Chen, L.; Zhao, J.; Ma, N. Characteristics of sewage sludge and distribution of heavy metal in plants with amendment of sewage sludge. J. Environ. Sci. 2006, 18, 1094-1100. [CrossRef]

5. Du, P.; Zhang, L.; Ma, Y.; Li, X.; Wang, Z.; Mao, K.; Wang, N.; Li, Y.; He, J.; Zhang, X.; et al. Occurrence and Fate of Heavy Metals in Municipal Wastewater in Heilongjiang Province, China: A Monthly Reconnaissance from 2015 to 2017. Water 2020, 12, 728. [CrossRef]

6. Zhang, X.; Wang, X.Q.; Wang, D.F. Immobilization of Heavy Metals in Sewage Sludge during Land Application Process in China: A Review. Sustainability 2017, 9, 2020. [CrossRef]

7. Turek, A.; Wieczorek, K.; Wolf, W.M. Digestion Procedure and Determination of Heavy Metals in Sewage Sludge-An Analytical Problem. Sustainability 2019, 11, 1753. [CrossRef]

8. Tytła, M. Assessment of Heavy Metal Pollution and Potential Ecological Risk in Sewage Sludge from Municipal Wastewater Treatment Plant Located in the Most Industrialized Region in Poland—Case Study. Int. J. Environ. Res. Public Health. 2019, 16, 2430. [CrossRef]

9. Okoh, A.T.; Odjadjare, E.E.; Igbinosa, E.O.; Osode, A.N. Wastewater treatment plants as a source of microbial pathogens in receiving water sheds. African J. Biotech. 2007, 6, 2932-2944.

10. McCasland, M.; Trautmann, N.; Porter, K.; Wagenet, R. Nitrate: Health Effects in Drinking Water. 2008. Available online: http://pmep.cee.comell.edu/facts.slides--self/facts/nit-heefgrw85.html (accessed on 20 July 2020).

11. Akpor, O.B. Wastewater Effluent Discharge: Effects and Treatment Processes. In Proceedings of the 3rd International Conference on Chemical, Biological and Environmental Engineering, Chengdu, China, 23-25 September 2011; IPCBEE: IACSIT Press: Singapore; Volume 20, pp. 85-91.

12. Ohoro, C.R.; Adeniji, A.O.; Okoh, A.I.; Okoh, O.O. Distribution and chemical analysis of pharmaceuticals and personal care products (PPCPS) in the aquatic systems: A review. Intl. J. Environ. Res. Public Health 2019, 16, 3026. [CrossRef]

13. Samer, M. Biological and Chemical Wastewater Treatment Processes. In Wastewater Treatment Engineering; Samer, M., Ed.; IntechOpen: London, UK, 2015.

14. Crini, G.; Lichtfouse, E. Advantages and disadvantages of techniques used for wastewater treatment. Environ. Chem. Lett. 2019, 17, 145-155. [CrossRef]

15. Suthar, S. Development of a novel epigeic-anecic-based polyculture vermireactor for efficient treatment of municipal sewage water sludge. Int. J. Environ. Waster Manag. 2008, 2, 84-101. [CrossRef]

16. Xing, M.; Zhao, L.; Yang, J.; Huang, Z.; Xu, Z. Distribution and transformation of organic matter during liquid-state vermiconversion of activated sludge using elemental analysis and spectroscopic evaluation. Environ. Eng. Sci. 2011, 28, 619-626. [CrossRef]

17. Morand, P.; Robin, P.; Qiu, J.P.; Li, Y.; Cluzeau, D.; Hamon, G.; Amblard, C.; Fievet, S.; Oudart, D.; Pain le Quere, C.; et al. Biomass production and water purification from fresh liquid manure by vermiculture, macrophytes ponds and constructed wetlands to recover nutrients and recycle water for flushing in pig housing. In Proceedings of the International Congress "Ecological Engineering: From Concepts to Applications Foreword (EECA)", Paris, France, 2-4 December 2009.

18. Li, X.; Xing, M.; Yang, J.; Huang, Z. Compositional and functional features of humic acid-like fractions from vermicomposting of sewage sludge and cow dung. J. Hazard. Mater. 2011, 185, 740-748. [CrossRef] 
19. Keller, C.; McGrath, S.P.; Dunham, S.J. Trace metal leaching through a soil-grassland system after sewage sludge application. J. Environ. Qual. 2002, 31, 1550-1560.

20. McLaren, R.G.; Clucas, L.M.; Taylor, M.D.; Hendry, T. Leaching of macronutrients and metals from undisturbed soils treated with metal-spiked sewage sludge. 2. Leaching of metals. Aust. J. Soil Res. 2004, 42, 459-471. [CrossRef]

21. Wuana, R.A.; Okieimen, F.E. Heavy Metals in Contaminated Soils: A Review of Sources, Chemistry, Risks and Best Available Strategies for Remediation. Intl. Sch. Res. Net. 2011, 2011, 20. [CrossRef]

22. Han, G.; Wen, S.; Wang, H.; Feng, Q. Selective adsorption mechanism of salicylic acid on pyrite surfaces and its application in flotation separation of chalcopyrite from pyrite. Sep. Purif. Technol. 2020, 240, 116650. [CrossRef]

23. Zhao, W.; Liu, D.; Feng, Q. Enhancement of salicylhydroxamic acid adsorption by Pb (II) modified hemimorphite surfaces and its effect on floatability. Miner. Eng. 2020, 152, 106373. [CrossRef]

24. Dinis, M.D.L.; Fiúza, L.I.A. Environmental Heavy Metal Pollution and Effects on Child Mental Development: Risk Assessment and Prevention Strategies; Simeonov, L.I., Kochubovski, M.V., Simeonova, B.G., Eds.; Springer: Berlin/Heidelberg, Germany, 2011; p. 344.

25. Titilawo, Y.; Adeniji, A.; Adeniyi, M.; Okoh, A. Determination of levels of some metal contaminants in the freshwater environments of Osun State, Southwest Nigeria: A risk assessment approach to predict health threat. Chemosphere 2018, 211, 834-843. [CrossRef]

26. Ali, H.; Khan, E.; Ilahi, I. Environmental Chemistry and Ecotoxicology of Hazardous Heavy Metals: Environmental Persistence, Toxicity, and Bioaccumulation. J. Chem. 2019, 2019, 14. [CrossRef]

27. Barakat, M.A. New trends in removing heavy metals from industrial wastewater. Arab. J. Chem. 2011, 4, 361-377. [CrossRef]

28. Khan, T.; Muhammad, S.; Khan, B.; Khan, H. Investigating the levels of selected heavy metals in surface water of shah alam river (a tributary of River Kabul, Khyber Pakhtunkhwa). J. Himal. Earth Sci. 2011, 44, 71-79.

29. Manoj, K.; Padhy, P.K.; Chaudhury, S. Study of heavy metal contamination of the river water through index analysis approach and environmetrics. Bull. Environ. Pharmacol. Life Sci. 2012, 1, 7-15.

30. Yi, Y.; Tang, C.; Yi, T.; Yang, Z.; Zhang, S. Health risk assessment of heavy metals in fish and accumulation patterns in food web in the upper Yangtze River, China. Eco. Env. Saf. 2017, 145, 295-302. [CrossRef]

31. Okoro, C.K.; Kingsley, R.A.; Connor, T.R.; Harris, S.R.; Parry, C.M.; Al-Mashhadani, M.N.; Wain, J. Intracontinental spread of human invasive Salmonella Typhimurium pathovariants in sub-Saharan Africa. Nat. Gene 2012, 44, 1215. [CrossRef]

32. El Bouraie, M.M.; El Barbary, A.A.; Yehia, M.M.; Motawea, E.A. Heavy metal concentrations in surface river water and bed sediments at Nile Delta in Egypt. Suoseurae Finn. Peatl. Soc. 2010, 61, 1-12.

33. Lokhande, S.; Singare, P.U.; Pimple, D.S. Pollution in water of Kasardi river flowing along Taloja industrial area of Mumbai, India ram. World Environ. 2011, 1, 6-13. [CrossRef]

34. Baby, J.; Raj, J.S.; Biby, E.T.; Sankarganesh, P.; Jeevitha, M.V.; Ajisha, S.U.; Rajan, S.S. Toxic effect of heavy metals on aquatic environment. Int. J. Biol. Chem. Sci. 2010, 4, 939-952. [CrossRef]

35. Shamuyarira, K.K.; Gumbo, J.R. Assessment of Heavy Metals in Municipal Sewage Sludge: A Case Study of Limpopo Province, South Africa. Int. J. Environ. Res. Public Health 2014, 11, 2569-2579. [CrossRef]

36. Olujimi, O.O.; Fatoki, O.S.; Odendaal, J.P.; Oputu, O.U. Variability in Heavy Metal Levels in River Water Receiving Effluents in Cape Town, South Africa. In Research and Practices in Water Quality; IntechOpen: London, UK, 2015.

37. Nyamukamba, P.; Moloto, M.J.; Tavengwa, N.; Ejidike, I.P. Evaluating Physicochemical Parameters, Heavy Metals, and Antibiotics in the Influents and Final Effluents of South African Wastewater Treatment Plants. Pol. J. Environ. Stud. 2019, 28, 1305-1312. [CrossRef]

38. Iloms, E.; Ololade, O.O.; Ogola, H.J.; Selvarajan, R. Investigating Industrial Effluent Impact on Municipal Wastewater Treatment Plant in Vaal, South Africa. J. Environ. Res. Public Health 2020, 17, 1096. [CrossRef]

39. Kinuthia, G.K.; Ngure, V.; Beti, D.; Lugalia, R.; Wangila, A.; Kamau, L. Levels of heavy metals in wastewater and soil samples from open drainage channels in nairobi, Kenya: Community health implication. Sci. Rep. 2020, 10, 1-13. [CrossRef]

40. Shanbehzadeh, S.; Vahid Dastjerdi, M.; Hassanzadeh, A.; Kiyanizadeh, T. Heavy metals in water and sediment: A case study of Tembi River. J. Environ. Res. Public Health 2014. [CrossRef] 
41. Mekki, A.; Sayadi, S. Study of heavy metal accumulation and residual toxicity in soil saturated with phosphate processing wastewater. Water Air Soil Pollut. 2017, 228, 215. [CrossRef]

42. Zhou, Y.; Lei, J.; Zhang, Y.; Zhu, J.; Lu, Y.; Wu, X.; Fang, H. Determining discharge characteristics and limits of heavy metals and metalloids for wastewater treatment plants (WWTPs) in China based on statistical methods. Water 2018, 10, 1248. [CrossRef]

43. Westerhoff, P.; Lee, S.; Yang, Y.; Gordon, G.W.; Hristovski, K.; Halden, R.U.; Herckes, P. Characterization, recovery opportunities, and valuation of metals in municipal sludges from US wastewater treatment plants nationwide. Environ. Sci. Technol. 2015, 49, 9479-9488. [CrossRef]

44. Agoro, M.A.; Okoh, O.O.; Adefisoye, M.A.; Okoh, A.I. Physicochemical Properties of Wastewater in Three Typical South African Sewage Works. Pol. J. Environ. Stud. 2018, 27, 491-499. [CrossRef]

45. Salaudeen, T.; Okoh, O.; Okoh, A. Performance assessment of wastewater treatment plants with special reference to phenol removal. Intl. J. Env. Sci. Tech. 2018, 16, 401-412. [CrossRef]

46. Salaudeen, T.; Okoh, O.; Agunbiade, F.; Okoh, A. Fate and impact of phthalates in activated sludge treated municipal wastewater on the water bodies in the Eastern Cape, South Africa. Chemosphere 2018, 203, 336-344. [CrossRef]

47. Ademoyegun, O.T.; Okoh, O.O.; Okoh, A.I. Organochlorine Pesticides in Selected Sewage Sludge in South Africa: Assessment and Method Validation. Pol. J. Environ. Stud. 2020, 29, 1021-1028. [CrossRef]

48. Salaudeen, T.; Okoh, O.; Agunbiade, F.; Okoh, A. Phthalates removal efficiency in different wastewater treatment technology in the Eastern Cape, South Africa. Environ. Monit. Assess. 2018, 190, 299. [CrossRef] [PubMed]

49. Gregg, L.W. Water Analysis Handbook; H.A.C.H Company: Loveland, CO, USA, 1989; pp. 33-39.

50. Bala, M.; Shehu, R.A.; Lawal, M. Determination of the Level of Some Heavy Metals in Water Collected from Two Pollution - Prone Irrigation Areas around Kano Metropolis. Bayero J. Pure Appl. Sci. 2008, 1, 36-38. [CrossRef]

51. Srikanth, P.; Somasekhar, S.A.; Kanthi, G.K.; Babu, K.R. Analysis of Heavy Metals by Using Atomic Absorption Spectro-Scopyfrom the Samples Taken Around Visakhapatnam. Intl. J. Environ. Ecol. Fam. Urban Stud. 2013, 3, 127-132.

52. Joseph, A.A.; Titilope, J.J.; Oguntimehin, I.I.; Lajide, L. Delineation of heavy metals in soils from auto-mechanic workshops within Okitipupa, Ondo State, Nigeria. Int. Res. J. Public Environ. Health 2017, 4, 136-147.

53. Kasselman, G. An Evaluation of Predictive Environmental Test Procedures for Sewage Sludge. Master's Thesis, University of Pretoria/Universiteit van Pretoria, Pretoria, South Africa, 2006.

54. Vuyolwethu, K.; Ojemaye, M.O.; Oyedeji, A.O.; Lewu, F.B.; Oyedeji, O.O. Assessment of the Heavy Metal Content of Wild and Cultivated Pelargonium Inquinans: An Herbal Plant Used For the Treatment of Diverse Ailments in South Africa. Fresenius Environ. Bull. 2018, 27, 3914-3919.

55. Tembeni, B.; Oyedeji, O.O.; Ejidike, I.P.; Oyedeji, A.O. Evaluation of Trace Metal Profile in Cymbopogon validus and Hyparrhenia hirta Used as Traditional Herbs from Environmentally Diverse Region of Komga, South Africa. J. Anal. Meth. Chem. 2016, 2016, 8. [CrossRef]

56. Kendir, E.; Kentel, E.; Sanin, F.D. Evaluation of Heavy Metals and Associated Health Risks in a Metropolitan Wastewater Treatment Plant's Sludge for Its Land Application. Hum. Eco. Risk Assess. 2015, 21, 1631-1643. [CrossRef]

57. Yahaya, A.; Okoh, O.O.; Okoh, A.I.; Adeniji, A.O. Occurrences of organochlorine pesticides along the course of Buffalo River in the Eastern Cape of South Africa and its health implications. Int. J. Env. Res. Public Health 2017, 14, 1372. [CrossRef]

58. Nkabinde, S.N.; Okonkwo, J.O.; Olukunle, O.I.; Daso, A.P. Determination of legacy and novel brominated flame retardants in dust from end of life office equipment and furniture from Pretoria, South Africa. Sci. Total Environ. 2018, 622-623, 275-281. [CrossRef]

59. Kumar, V.; Chopra, A.K. Fertigation effect of distillery effluent on agronomical practices of Trigonella foenum-graecum L. (Fenugreek). Environ. Monit. Assesst. 2012, 184, 1207. [CrossRef] [PubMed]

60. Praveena, S.M.; Ismail, S.N.S.; Aris, A.Z. Health risk assessment of heavy metal exposure in urban soil from Seri Kembangan (Malaysia). Arab. J. Geosci. 2015, 8, 9753-9761. [CrossRef] 
61. Tepanosyan, G.; Sahakyan, L.; Belyaeva, O.; Maghakyan, N.; Saghatelyan, A. Human health risk assessment and riskiest heavy metal origin identification in urban soils of Yerevan, Armenia. Chemosphere 2017, 184, 1230-1240. [CrossRef]

62. USEPA (United States Environmental Protection Agency). A Guide to the Biosolids Risk Assessments for the EPA Part 503 Rule; U.S. Environmental Protection Agency Office of Wastewater Management: Washington, DC, USA, 1995.

63. Kamunda, C.; Mathuthu, M.; Madhuku, M. Health Risk Assessment of Heavy Metals in Soils from Witwatersrand Gold Mining Basin, South Africa. Int. J. Environ. Res. Public Health 2016, 13, 663. [CrossRef]

64. Pan, L.; Ma, J.; Hu, Y.; Su, B.; Fang, G.; Wang, Y.; Wang, Z.S.; Wang, L.; Xiang, B. Assessments of levels, potential ecological risk, and human health risk of heavy metals in the soils from a typical county in Shanxi province, China. Environ. Sci. Pollut. Res. 2016, 23, 19330-19340. [CrossRef] [PubMed]

65. Risk assessment Guidance for Superfund Volume I, Human Health Evaluation Manual (part a): Interim Fnal; USEPA (United States Environmental Protection Agency): Washington, DC, USA, 1989; Volume 289, EPA/540/1-89/002; PB90-155581.

66. USEPA (United States Environmental Protection Agency). Regional Screening Table. Updated 2015, 176. Available online: https://semspub.epa.gov/work/10/500011899.pdf. (accessed on 8 August 2020).

67. Wang, X.; Sato, T.; Xing, B. Health risks of heavy metals to the general public in Tianjin, China via consumption of vegetables and fish. Sci. Total Environ. 2005, 350, 28-37. [CrossRef]

68. Duan, B.; Zhang, W.; Zheng, H.; Wu, C.; Zhang, Q.; Bu, Y. Comparison of Health Risk Assessments of Heavy Metals and As in Sewage Sludge from Wastewater Treatment Plants (WWTPs) for Adults and Children in the Urban District of Taiyuan, China. Int. J. Environ. Res. Public Health 2017, 14, 1194. [CrossRef]

69. Adedokun, A.H.; Njoku, K.L.; Akinola, M.O.; Adesuyi, A.A.; Jolaoso, A.O. Potential Human Health Risk Assessment of Heavy Metals Intake via Consumption of some Leafy Vegetables obtained from Four Market in Lagos Metropolis, Nigeria. J. Appl. Sci. Environ. Manag. 2016, 20, 530-539. [CrossRef]

70. Elumalai, V.; Brindha, K.; Lakshmanan, E. Human Exposure Risk Assessment Due to Heavy Metals in Groundwater by Pollution Index and Multivariate Statistical Methods: A Case Study from South Africa. Water 2017, 9, 234. [CrossRef]

71. Ngole-Jeme, V.M.; Fantke, P. Ecological and human health risks associated with abandoned gold mine tailings contaminated soil. PLOS ONE 2017, 12, 0172517. [CrossRef]

72. Liang, Y.; Yi, X.; Dang, Z.; Wang, Q.; Luo, H.; Tang, J. Heavy Metal Contamination and Health Risk Assessment in the Vicinity of a Tailing Pond in Guangdong, China. Int. J. Environ. Res. Public Health 2017, 14, 1557. [CrossRef] [PubMed]

73. Adeniji, A.O.; Okoh, O.O.; Okoh, A.I. Distribution pattern and health risk assessment of polycyclic aromatic hydrocarbons in the water and sediment of Algoa Bay, South Africa. Environ. Geochem. Health 2019, 41, 1303-1320. [CrossRef] [PubMed]

74. Adeniji, A.O.; Okoh, O.O.; Okoh, A.I. Levels of polycyclic aromatic hydrocarbons in the water and sediment of Buffalo River Estuary, South Africa and their health risk assessment. Arch. Environ. Contam. Toxicol. 2019, 76, 657-669. [CrossRef] [PubMed]

75. Onyedikachi, U.B.; Belonwu, D.C.; Wegwu, M.O. Human health risk assessment of heavy metals in soils and commonly consumed food crops from quarry sites located at Isiagwu, Ebonyi State. Ovidius Univ. Ann. Chem. 2018, 29, 8-24. [CrossRef]

76. Gebeyehu, H.R.; Bayissa, L.D. Levels of heavy metals in soil and vegetables and associated health risks in Mojo area, Ethiopia. PLoS ONE 2020, 15, 0227883. [CrossRef] [PubMed]

77. USEPA (United States Environmental Protection Agency). Biosolids Generation, Use and Disposal in the United States; EPA530-R-99-009; Office of Solid Waste and Emergency Response: Washington, DC, USA, 1999.

78. Shomar, B.H.; Muller, G.; Yahya, A. Potential use of treated wastewater and sludge in the agricultural sector of the Gaza Strip. Clean Technol. Environ. Policy 2004, 6, 128-137.

79. WHO (World Health Organization). Guidelines for Drinking-Water Quality: Recommendations Incorporating 1st and 2nd Addenda, 13th ed.; World Health Organization: Geneva, Switzerland, 2008.

80. USEPA (United States Environmental Protection Agency). Edition of the Drinking Water Standards and Health Advisories; EPA 822-S-12-001; Office of Water U.S. Environmental Protection Agency: Washington, DC, USA, 2012. 
81. Idoko, O.M.; Ologunorisa, T.E.; Okoya, A.A. Temporal variability of heavy metals concentration in rural groundwater of Benue State, Middle Belt, Nigeria. J. Sustain. Dev. 2012, 5, 1-16. [CrossRef]

82. DWAF (Department of Water Affairs and Forestry). South Africa Water Quality Guidelines, (Domestic Use), 2nd ed.; DWAF: Pretoria, South Africa, 1996; Volume 1, pp. 39-41.

83. WHO (World Health Organization). Guidelines for Drinking-Water Quality: Fourth Edition Incorporating the First Addendum; WHO: Cham, Switzerland, 2017; Volume 631, ISBN 978-92-4-154995-0.

84. Okonkwo, J.O.; Mothiba, M. Physico-chemical characteristics and pollution levels of heavy metals in the rivers in Thohoyandou, South Africa. J. Hydrol. 2005, 308, 122-127. [CrossRef]

85. Wilderer, P.A.; Kolb, F.R. Activated Carbon Sequencing Batch Biofilm Reactor to Treat Industrial waste-Water. Water Sci. Technol. 1997, 35, 169-176.

86. Fatoki, O.S.; Lujiza, N.; Ogunfowokan, A.O. Trace metal pollution in the Umtata River. Water SA 2002, 28, 183-190. [CrossRef]

87. Awofolu, O.R.; Mbolekwa, Z.; Mtshemla, V.; Fatoki, O.S. Levels of trace metals in water and sediment from Tyume river and its effects on an irrigated farm-land. Water $S A$ 2005, 31, 87-94. [CrossRef]

88. ENVIRODAT. National Environmental Quality Data Bank Codes Dictionary; Ottawa, Water Quality Branch, Inland Waters Directorate, Environment Canada: Ottawa, ON, Canada, 1992.

89. Teijon, G.; Candela, L.; Tamoh, K.; Molina-Diaz, A.; Fernandez-Alba, A.R. Occurrence of emerging contaminants, priority substances (2008/105/CE) and heavy metals in treated wastewater and groundwater at Depurbaix facility (Barcelona, Spain). Sci. Total Environ. 2010, 408, 3584-3595. [CrossRef] [PubMed]

90. Zhou, Q.; Yang, N.; Li, Y.; Ren, B.; Ding, X.; Bian, H.; Yao, X. Total concentrations and sources of heavy metal pollution in global river and lake water bodies from 1972 to 2017. Glob. Ecol. Conserv. 2020, 22, 00925. [CrossRef]

91. DWAF (Department of Water Affairs and Forestry). Strategic Plan 2010/11-2012; DWAF: Pretoria, South Africa, 2010.

92. USEPA (United States Environmental Protection Agency). Supplemental Guidance for Developing Soil Screening Levels for Superfund Sites; Office of Emergency and Remedial Response: Washington, DC, USA, 2002.

93. Tiruneh, A.T.; Fadiran, A.O.; Mtshali, J.S. Evaluation of the risk of heavy metals in sewage sludge intended for agricultural application in Swaziland. Intl. J. Env. Sci. 2014, 5, 197-216.

94. Eriksson, J. Concentrations of 61 Trace Elements in Sewage Sludge, Farmyard Manure, Mineral Fertiliser, Precipitation and in Oil and Crops; Swedish Environmental Protection Agency: Stockholm, Sweden, 2001; Volume 5159.

95. Morrison, G.; Fatoki, O.; Linder, S.; Lundehn, C. Determination of heavy metal concentrations and metal fingerprints of sewage sludge from Eastern Cape Province South Africa by ICP-MS and LA-ICP-MS. Water Air Soil Poll. 2004, 152, 111-127. [CrossRef]

96. Akpor, O.B.; Ohiobor, G.O.; Olaolu, T.D. Heavy metal pollutants in wastewater effluents: Sources, effects and remediation. $A B B$ 2014, 2, 37. [CrossRef]

97. Rattan, R.; Datta, S.; Chhonkar, P.; Suribabu, K.; Singh, A. Long-term impact of irrigation with sewage effluents on heavy metal content in soils, crops and groundwater-A case study. Agric. Econ. Environ. 2005, 109, 310-322. [CrossRef]

98. Hussain, A.; Priyadarshi, M.; Dubey, S. Experimental study on accumulation of heavy metals in vegetables irrigated with treated wastewater. Appl. Water Sci. 2019, 9, 122. [CrossRef]

99. Adekunle, A.S.; Oyekunle, J.A.O.; Ojo, O.S.; Maxakato, N.W.; Olutona, G.O.; Obisesan, O.R. Determination of polycyclic aromatic hydrocarbon levels of groundwater in Ife north local government area of Osun state, Nigeria. Toxicol. Rep. 2017, 4, 39-48. [CrossRef]

100. John, D.A.; Leventhal, J.S. Bioavailability of Metals. In Preliminary Compilation of Descriptive Geoenvironmental Mineral Deposit Models; du Bray, E.A., Ed.; U.S. Department of the Interior: Washington, DC, USA; U.S. Geological Survey: Denver, CO, USA, 1995; pp. 95-831.

101. Edokpayi, J.N.; Odiyo, J.O.; Popoola, O.E.; Msagati, T.A.M. Assessment of Trace Metals Contamination of Surface Water and Sediment: A Case Study of Mvudi River, South Africa. Sustainability 2016, 8, 135. [CrossRef]

102. Godwin, A.; Oghenekohwiroro, E.; Funso, A.; Olaniyi, O. Using EF, PLI and IGEO for the assessment of heavy metal pollution and sediment quality of Asejire Reservoir, Southwest Nigeria. Int. J. Environ. Pollut. Res. 2015, 3, 77-90. 
103. Jaishankar, M.; Tseten, T.; Anbalagan, N.; Mathew, B.B.; Beeregowda, K.N. Toxicity, mechanism and health effects of some heavy metals. Interdiscip Toxicol. 2014, 7, 60-72. [CrossRef]

104. Grant, C.A.; Sheppard, S.C. Fertilizer impacts on cadmium availability in agricultural soils and crops. Hum. Eco. Risk Assess. An Intl. J. 2008, 14, 210-228. [CrossRef]

105. Murtaza, G.; Javed, W.; Hussain, A.; Wahid, A.; Murtaza, B.; Owens, G. Metal uptake via phosphate fertilizer and city sewage in cereal and legume crops in Pakistan. Env. Sci. Poll. Res. 2015, 22, 9136-9147. [CrossRef] [PubMed]

106. Satarug, S.; Garrett, S.H.; Sens, M.A.; Sens, D.A. Cadmium, environmental exposure, and health outcomes. Ciência Saúde Coletiva 2011, 16, 2587-2602. [CrossRef] [PubMed]

107. Irfan, M.; Hayat, S.; Ahmad, A.; Alyemeni, M.N. Soil cadmium enrichment: Allocation and plant physiological manifestations. Saudi J. Biol. Sci. 2013, 20, 1-10. [CrossRef]

108. Sharma, H.; Rawal, N.; Mathew, B.B. The Characteristics, Toxicity and Effects of Cadmium. Intl. J. Nanotech. Nanosci. 2015, 3, 1-9.

109. European Communities. Pollutants in Urban Wastewater and Sewage Sludge; Final Report; ICON IC Consultants Ltd.: London, UK, 2001; p. 273.

110. Alloway, B.J. Sources of heavy metals and metalloids in soils. In Heavy Metals in Soils: Trace Metals and Metalloids in Soils and their Bioavailability; Springer: Dordrecht, The Netherlands, 2013; pp. 11-50.

111. Dawaki, M.U.; Dikko, A.U.; Noma, S.S.; Aliyu, U.A. Pollution as a threat factor to urban food security in metropolitan Kano, Nigeria. Food Energy Secur. 2013, 2, 20-33. [CrossRef]

112. Xue, W.C.; Wu, C.Y.; Xiao, K.; Huang, X.; Zhou, H.D.; Tsuno, H.; Tanaka, H. Elimination and fate of selected micro-organic pollutants in a full-scale anaerobic/anoxic/aerobic process combined with membrane bioreactor for municipal wastewater reclamation. Water Res. 2010, 44, 5999-6010. [CrossRef]

113. Wett, B.; Buchauer, K. Comparison of aerobic and anaerobic technologies for domestic wastewater treatment based on case studies in Latin America. Semin. Probl. Soluc. Ambient. Aguas Residuales Residuos Solidos. Available online: http://www.pseau.org/outils/ouvrages/universidad_nacional_de_colombia_comparison_ of_aerobic_and_anaerobic_technologies_for_domestic_wastewater_treatment_based_on_case_studies_in_ latin_america_2003.pdf (accessed on 19 July 2020).

114. Byrns, G. The fate of xenobiotic organic compounds in wastewater treatment plants. Water Res. 2001, 35, 23-33. [CrossRef]

115. Dargnat, C.; Teil, M.J.; Chevreuil, M.; Blanchard, M. Phthalate removal throughout wastewater treatment plant. Case study of Marne Aval station (France). Sci. Total Environ. 2009, 407, 1235-1244. [CrossRef] [PubMed]

116. Isaeva, M.; Castro, N.M. Water Treatment for the Removal of Iron and Manganese. Bachelor Degree Project in Mechanical Engineering. Dev. Assist. 2011, 30, 48.

117. Sandeep, R.D. Biofiltration Treatment for Iron- and Manganese-Rich Groundwater at Low On-Site Temperatures. Master's Thesis, Department of Civil, Geological and Environmental Engineering, University of Saskatchewan, Saskatoon, Canada, 2017.

118. Zeng, H.; Yin, C.; Zhang, J.; Li, D. Start-Up of a Biofilter in a Full-Scale Groundwater Treatment Plant for Iron and Manganese Removal. Int. J. Environ. Res. Public Health 2019, 16, 698. [CrossRef] [PubMed]

119. Li, F.; Qiu, Z.; Zhang, J.; Liu, C.; Cai, Y.; Xiao, M. Spatial distribution and fuzzy health risk assessment of trace elements in surface water from Honghu Lake. Int. J. Environ. Res. Public Health 2017, 14, 1011. [CrossRef] [PubMed]

120. Haque, M.A.; Jewel, M.A.; Ferdoushi, Z.; Begum, M.; Husain, M.I.; Mondal, S. Carcinogenic and Non-carcinogenic Human Health Risk from Exposure to Heavy Metals in Surface Water of Padma River. Res. J. Environ. Toxicol. 2018, 12, 18-23.

(C) 2020 by the authors. Licensee MDPI, Basel, Switzerland. This article is an open access article distributed under the terms and conditions of the Creative Commons Attribution (CC BY) license (http://creativecommons.org/licenses/by/4.0/). 